PRAXEDES, C.I.S., CARRIJO, K.F., FREIRE, R.G.S. Controle físico-químico de água de abastecimento para consumo e uso industrial: sistema de tratamento, métodos de análise e parâmetros legais. PUBVET, Londrina, V. 6, N. 26, Ed. 213, Art. 1420, 2012.

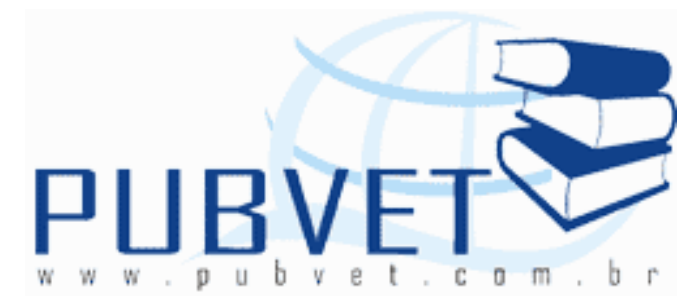

PUBVET, Publicações em Medicina Veterinária e Zootecnia.

\title{
Controle físico-químico de água de abastecimento para consumo e uso industrial: sistema de tratamento, métodos de análise e parâmetros legais
}

Carla Inês Soares Praxedes ${ }^{1 *}$; Kênia de Fátima Carrijo ${ }^{2}$; Renata Groetaers da Silva Freire ${ }^{3}$

${ }^{1 *}$ Centro Federal de Educação Tecnológica Celso Suckow da Fonseca - CEFET Núcleo Avançado de Valença. Endereço: Rua Rui Barbosa, n.121, Apto. 304, Centro, Valença-RJ, CEP: 27.600-000, Valença-RJ, Brasil. Telefone: (24) 24521932. Email: cispraxedes@hotmail.com

2Docente da Faculdade de Medicina Veterinária, Universidade Federal de Uberlândia (UFU), Uberlândia-MG, Brasil.

${ }^{3}$ Docente do Centro Interescolar de Agropecuária Monsenhor Tomás Tejerina de Prado, Valença-RJ, Brasil.

\section{Resumo}

O objetivo do presente trabalho foi realizar um levantamento bibliográfico sobre a análise físico-química da água de abastecimento e residuais, ressaltando a importância da água e da sua qualidade para a manutenção da vida, do sistema de abastecimento de água para consumo humano e seu tratamento, até a realização propriamente dita das análises físico-químicas de interesse aos órgãos governamentais. A execução das análises laboratoriais para o controle e vigilância fornecem uma indicação de sua qualidade, 
PRAXEDES, C.I.S., CARRIJO, K.F., FREIRE, R.G.S. Controle físico-químico de água de abastecimento para consumo e uso industrial: sistema de tratamento, métodos de análise e parâmetros legais. PUBVET, Londrina, V. 6, N. 26, Ed. 213, Art. 1420, 2012.

auxiliando na verificação e monitoramento dos padrões pelo governo federal, estadual e municipal baseados na legislação vigente. Quando se seleciona a tecnologia e o sistema de tratamento, é vital que todas as informações acerca da fonte de água sejam coletadas. Isso é importante para conhecer como se comporta a água antes de tentar estabelecer o sistema de tratamento adequado. Do mesmo modo é fundamental realizar um programa de monitoramento na Estação de Tratamento de Água (ETA), de forma a avaliar cada estágio do tratamento no que se refere a sua eficácia e eficiência. As características das águas potáveis variam, sendo de grande importância a metodologia analítica para determinação dos parâmetros físico-químicos que avaliam essas propriedades e devem atender às especificações das normas nacionais. Portanto, antes da escolha do método, deve-se conhecer a natureza da água e definir o que se quer analisar para que se tenha resultados satisfatórios.

Palavras-chave: água, resíduo, físico-química, qualidade.

\title{
Physical and chemical control of fresh water for consumption and industrial use: system of treatment, analysis methods and legal parameters
}

\begin{abstract}
The aim of this study was a literature on the physical-chemical analysis of water supply and sewage, highlighting the importance of water and its quality of life for the maintenance of the supply system for drinking water and its treatment until the actual performance of physical-chemical analyzes of interest to government agencies. The execution of laboratory tests for the control and surveillance provide an indication of its quality, assisting in the verification and monitoring of standards by the federal government, state and municipal-based legislation. When selecting technology and treatment system is vital that all information about the source of water is collected. This is important to know how the water behaves before attempting to establish the
\end{abstract}


PRAXEDES, C.I.S., CARRIJO, K.F., FREIRE, R.G.S. Controle físico-químico de água de abastecimento para consumo e uso industrial: sistema de tratamento, métodos de análise e parâmetros legais. PUBVET, Londrina, V. 6, N. 26, Ed. 213, Art. 1420, 2012.

system of treatment. Similarly, it is essential to implement a program for monitoring the Water Treatment Station, in order to evaluate each stage of treatment with regard to their effectiveness and efficiency. The characteristics of drinking water vary, being of great importance to the analytical methodology for determination of physico-chemical parameters that assess these properties and specifications must meet national standards. Therefore, before choosing the method, one must know the nature of water and set what you want to analyze in order to have satisfactory results.

Keywords: water, waste, physico-chemical quality.

\section{INTRODUÇÃO}

A fixação do homem em uma determinada região está intimamente ligada à disponibilidade quantitativa e qualitativa de três elementos fundamentais para sua sobrevivência: o alimento, o ar e a água. Foi esta necessidade que nele fixou a tendência natural de se estabelecer próximo aos cursos $d^{\prime}$ água, pois dos três elementos vitais é a água que não se encontra distribuída uniformemente, como o ar, e que não pode ser fabricada, como os alimentos (FUNASA, 2003).

A água constitui, portanto, um elemento essencial à vida animal e vegetal. Seu papel no desenvolvimento da civilização é reconhecido desde a antiguidade. $\mathrm{O}$ homem tem necessidade de água de qualidade adequada e em quantidade suficiente, não somente para proteção de sua saúde, como também para seu desenvolvimento econômico (ibid.).

Até pouco tempo atrás a água era considerada um recurso infinito na natureza. A generosidade da natureza fazia crer em inesgotáveis mananciais, abundantes e renováveis. Esse conceito, até certo ponto é válido, se considerar-se o total da água do planeta, já que o volume total da água permanece constante no planeta, sendo estimado em torno de 1,4 bilhão de quilômetros cúbicos. Todavia, esse enfoque é totalmente falso quando se considera somente a água potável (ONU, 1992). 
PRAXEDES, C.I.S., CARRIJO, K.F., FREIRE, R.G.S. Controle físico-químico de água de abastecimento para consumo e uso industrial: sistema de tratamento, métodos de análise e parâmetros legais. PUBVET, Londrina, V. 6, N. 26, Ed. 213, Art. 1420, 2012.

Atualmente, o uso de forma irracional, aliado à crescente demanda pelo recurso, vem preocupando especialistas e autoridades no assunto, pelo evidente decréscimo da disponibilidade de água limpa em todo o planeta (UNIVERSIDADE DA ÁGUA, 2008).

Recurso natural de valor econômico, estratégico e social, essencial à existência e bem estar do homem e à manutenção dos ecossistemas do planeta, a água é um bem comum a toda a humanidade (ibid.).

A simplicidade da composição química parece disfarçar a importância da água para o desenvolvimento e preservação de todas as formas de vida existente na Terra. Sem a água, que constitui $70 \%$ do corpo humano, a vida, tal como a conhecemos, não seria possível (ibid.).

A água cobre $75 \%$ da superfície da Terra, sendo que a água salgada, presente nos mares e oceanos, representa $97,5 \%$ desse total, conforme mostrado na figura 1. A água doce, portanto, não chega a $3 \%$, sendo que $90 \%$ desse volume corresponde à geleiras e o restante, ou seja $0,007 \%$ do total da água do planeta corresponde à água "doce" dos rios, lagos e lençóis subterrâneos. Essa á a água de mais fácil acesso e que está disponível ao consumo humano. Levando-se em conta a dificuldade representada pelos elevados custos e alta tecnologia necessária ao aproveitamento da água salgada para consumo humano, tem-se uma boa noção da importância da preservação dos mananciais. (ibid.).

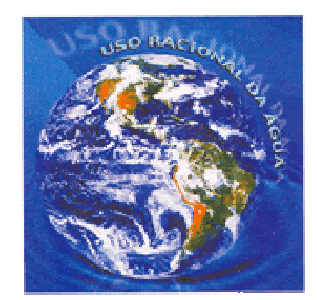

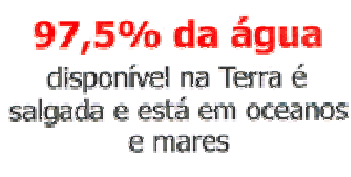

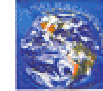

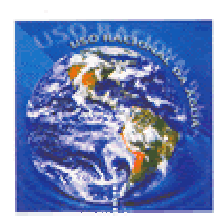

\section{$0,007 \%$ é doce}

encontrada em rios, lagos e na atmosfera, de fácil acesso para o consumo humano

\section{$2,493 \%$ é doce mas se encontra em geleiras ou regiões subterrâneas (aqǘfferos), de difícil acesso}

Figura 1 Água no mundo

Fonte www.sabesp.com.br 
PRAXEDES, C.I.S., CARRIJO, K.F., FREIRE, R.G.S. Controle físico-químico de água de abastecimento para consumo e uso industrial: sistema de tratamento, métodos de análise e parâmetros legais. PUBVET, Londrina, V. 6, N. 26, Ed. 213, Art. 1420, 2012.

No Quadro 1 podem ser observados os volumes de água relativos a cada uma das formas em que a água é encontrada no planeta:

Quadro 1. Distribuição da água na Terra

\begin{tabular}{lll}
\hline Tipo & Ocorrência & Volumes (km3) \\
\hline \multirow{2}{*}{ Água doce superficial } & Rios & 1.250 \\
& Lagos & 125.000 \\
\multirow{2}{*}{ Água doce subterrânea } & Umidade do solo & 67.000 \\
& Até 800 metros & 4.164 .000 \\
& Abaixo de 800 metros & 4.164 .000 \\
Água doce sólida (gelo) & Geleiras e Glaciais & 29.200 .000 \\
\multirow{2}{*}{ Água salgada } & Oceanos & 1.320 .000 .000 \\
Vapor de água & Lagos e mares salinos & 105.000 \\
\hline TOTAL & Atmosfera & 12.900 \\
\hline
\end{tabular}

Fonte: ZIMBRES (2008)

Segundo dados do PACIFIC INSTITUTE (2008), atualmente a água é um dos recursos naturais em situação mais crítica no mundo, constituindo-se, a sua proteção e preservação, em uma das maiores preocupações para a humanidade. O consumo global per capita, em 1996 foi de 12,6 litros/ano, crescendo para mais de 24 litros/ano em 2004, todavia esse crescimento apresenta imensa disparidade entre as diferentes regiões. Enquanto na Europa o valor médio chega a 97 litros por pessoa/ano, na África, no Oriente Médio e na Oceania aproximam-se de 4,4 litros/ano (Quadro 2).

O Brasil detém $11,6 \%$ da água doce superficial do mundo. Os $70 \%$ da água disponíveis para uso estão localizados na Região Amazônica e os 30\% restantes distribuem-se desigualmente pelo País, para atender a 93\% da população (UNIVERSIDADE DA ÁGUA, 2008). 
PRAXEDES, C.I.S., CARRIJO, K.F., FREIRE, R.G.S. Controle físico-químico de água de abastecimento para consumo e uso industrial: sistema de tratamento, métodos de análise e parâmetros legais. PUBVET, Londrina, V. 6, N. 26, Ed. 213, Art. 1420, 2012.

A importância e essencialidade da água para a humanidade são realçadas no documento "Declaração Universal dos Direitos da Água" (ONU, 1992), redigido pela Organização das Nações Unidas, em 22 de março de 1992, o qual merece a ciência de todo ser humano, além de profunda reflexão e divulgação (CETESB, 2008).

Quadro 2. Consumo mundial per capita de água, por região, de 1997 a 2004 (em litros)

\begin{tabular}{lrrrrrrrr}
\hline Regiões & 1997 & 1998 & 1999 & 2000 & 2001 & 2002 & 2003 & 2004 \\
\hline América do Norte & 59,4 & 59,7 & 68,0 & 72,2 & 77,9 & 85,2 & 91,8 & 97,5 \\
Europa & 47,8 & 50,3 & 55,6 & 58,8 & 61,9 & 65,5 & 72,1 & 74,7 \\
América do Sul & 14,8 & 16,9 & 19,2 & 22,1 & 25,3 & 28,5 & 31,2 & 33,2 \\
Ásia & 3,7 & 4,3 & 5,1 & 6,0 & 7,0 & 8,3 & 9,0 & 9,7 \\
África/Oriente & 2,6 & 2,9 & 3,1 & 3,4 & 3,7 & 4,1 & 4,2 & 4,4 \\
Médio/Oceania & & & & & & & & \\
\hline TOTAL & 13,8 & 14,8 & 16,4 & 17,8 & 19,3 & 21,3 & 23,0 & 24,2 \\
\hline
\end{tabular}

PACIFIC INSTITUTE (2008) - Per capita bottled water consumption by region, 1997 to 2004*.

* Dados preliminares

Hoje, o mau uso, aliado à crescente demanda pelo recurso, vem preocupando especialistas e autoridades no assunto, pelo evidente decréscimo da disponibilidade de água limpa em todo o planeta. Recurso natural de valor econômico, estratégico e social, essencial à existência e bem estar do homem e à manutenção dos ecossistemas do planeta, a água é um bem comum a toda a humanidade (UNIVERSIDADE DA ÁGUA, 2008).

A água é importante para a manutenção da vida e a sua sanidade e utilização racional são de impacto para a economia e preservação da saúde da coletividade. Constitui preocupação universal a presença de elementos patogênicos na água de consumo público. Preocupação idêntica estende-se às 
PRAXEDES, C.I.S., CARRIJO, K.F., FREIRE, R.G.S. Controle físico-químico de água de abastecimento para consumo e uso industrial: sistema de tratamento, métodos de análise e parâmetros legais. PUBVET, Londrina, V. 6, N. 26, Ed. 213, Art. 1420, 2012.

águas de uso industrial, em vista da possibilidade de, por via direta ou indireta, contaminarem-se os produtos e o pessoal envolvido. Pela sua constituição física e química, a água exerce também, influência sobre os produtos e na preservação de equipamentos. Portanto, impõem-se a todos os estabelecimentos que produzam ou manipulem alimentos o uso sistemático de água potável que, em algumas circunstâncias, deverá ser esterilizada ou condicionada para ser usada com determinados propósitos (PARDI, 1995).

As águas são captadas de mananciais superficiais (rios, fontes, minas) e subterrâneos (poços). De acordo com a origem e tratamento recebido, as características das águas potáveis variam, sendo de grande importância o conjunto de determinações físico-químicas que avaliam essas propriedades. Esses referidos ensaios são destinados à verificação da qualidade de águas provenientes de poços, minas, água mineral e de abastecimento público (SILVA, 1990).

Os órgãos governamentais estabelecem padrões de potabilidade, monitorando e inspecionando a qualidade da água, por isso, a execução das análises realizadas pelos laboratórios de referência nacional é de extrema importância auxiliando na verificação, monitoramento e fiscalização desses padrões. Assim sendo, o presente trabalho tem como objetivo apresentar a metodologia adotada pelos laboratórios de referência nacional para execução das principais análises de água e residuais de acordo com a legislação vigente.

\section{REVISÃO DE LITERATURA}

A seguir serão abordados alguns itens sobre o histórico e atuação da Organização Pan-Americana da Saúde/Organização Mundial da Saúde (OPAS/OMS) nos programas de monitoramento do setor de abastecimento de água; definição de água potável, formação da água na natureza, necessidade de implantação de sistema de abastecimento de água, tratamento da água, coleta de amostras e análises físico-químicas. 
PRAXEDES, C.I.S., CARRIJO, K.F., FREIRE, R.G.S. Controle físico-químico de água de abastecimento para consumo e uso industrial: sistema de tratamento, métodos de análise e parâmetros legais. PUBVET, Londrina, V. 6, N. 26, Ed. 213, Art. 1420, 2012.

\subsection{HISTÓRICO E ATUAÇÃO DA OPAS/OMS}

A OPAS/OMS tem estado, historicamente, na linha de frente de iniciativas e programas de monitoramento do setor de saneamento básico e abastecimento de água. Esse papel foi incrementado ainda mais depois da Conferência Especial das Nações Unidas sobre Água, realizada em Mar del Plata, Argentina, em 1977. O Plano de Ação de Mar del Plata recomendou que o período 1981 - 1990 fosse designado como a Década Internacional de Água Potável e Saneamento. O objetivo era "proporcionar a todos os habitantes do planeta, até 1990, água segura e em quantidade adequada, bem como prover instalações sanitárias básicas e dar prioridade aos pobres e menos privilegiados" (FERREIRA JúNIOR, 2002).

Apesar dos esforços realizados pela OPAS/OMS e seus países membros durante a "Década", quando 160 milhões de pessoas tiveram acesso à água potável e a sistemas de escoamento de esgoto, a situação, atualmente, é pior do que aquela de 1990, devido ao rápido crescimento populacional e à lenta expansão da cobertura de abastecimento e saneamento básico. Na região das Américas e do Caribe, por exemplo, a população total com acesso a água potável caiu de 79\% em 1988 para 73\% em 1995 (ibid.).

Em 1990, durante a Reunião Consultiva Mundial sobre Água Potável e Saneamento Ambiental para a Década de 90, ocorrida na Índia, foi aprovada a Declaração de Nova Delhi, reconhecendo formalmente a necessidade de facilitar, para todos, sob uma base sustentável, o acesso à água potável em quantidade suficiente e o estabelecimento de serviços de saneamento adequados. O princípio era "algo para todos e não muito para uns poucos" (ibid.).

Em 1992, durante a Conferência das Nações Unidas para o Meio Ambiente e Desenvolvimento, no Rio de Janeiro, os países membros da ONU aprovaram a Declaração do Rio sobre Meio Ambiente e Desenvolvimento. Conhecida como Agenda 21, a declaração é um plano de ação a ser adotado, globalmente, nacionalmente e localmente pelas Nações Unidas e governos, em 
PRAXEDES, C.I.S., CARRIJO, K.F., FREIRE, R.G.S. Controle físico-químico de água de abastecimento para consumo e uso industrial: sistema de tratamento, métodos de análise e parâmetros legais. PUBVET, Londrina, V. 6, N. 26, Ed. 213, Art. 1420, 2012.

todas as áreas onde há impacto do ser humano sobre o meio ambiente. No Capítulo 18, sobre Água Potável, é reforçado o objetivo de "satisfazer as necessidades de água potável de todos os países, de modo a assegurar seu desenvolvimento sustentável". No documento, afirma-se que " $80 \%$ de todas as doenças e pelo menos um terço das mortes nos países em desenvolvimento estão associados à água. Pelo menos um décimo da vida produtiva das pessoas é sacrificada devido a doenças relacionadas à água" (FUNASA, 2003).

Em março de 2000 foi lançado o programa Visão 21 - "Água para as Pessoas", sob os auspícios do Conselho para Abastecimento de Água e Saneamento (WSSCC), uma organização internacional, baseada em Genebra, que congrega profissionais de mais de 130 países, ligados à área (ibid.).

O programa tem como objetivo, até 2015 , reduzir pela metade o número de pessoas sem acesso às instalações sanitárias adequadas e assegurar quantidades de água segura e de custo acessível. Em termos concretos, isso significa levar serviços de água tratada a quase 300.000 pessoas todos os dias nos próximos quinze anos, e melhorar as instalações sanitárias para cerca de 400.000 pessoas por dia. E até 2025 , obter acesso universal aos serviços de abastecimento de água tratada e saneamento básico (ibid.).

\subsection{DEFINIÇÃO}

Tendo como definição, água para o consumo humano é aquela cujos parâmetros microbiológicos, físico-químicos e radioativos atendem aos padrões de potabilidade e não oferecem risco à saúde da população (BRASIL, 2004).

\subsection{FORMAÇÃO DA ÁGUA NA NATUREZA - CICLO HIDROLÓGICO - CICLO DAS ÁGUAS}

A água pura $\left(\mathrm{H}_{2} \mathrm{O}\right)$ é um líquido formado por dois átomos de hidrogênio e um de oxigênio e os cientistas acreditam que a mesma apareceu no planeta a cerca de 4,5 bilhões de anos atrás (CETESB, 2008). 
PRAXEDES, C.I.S., CARRIJO, K.F., FREIRE, R.G.S. Controle físico-químico de água de abastecimento para consumo e uso industrial: sistema de tratamento, métodos de análise e parâmetros legais. PUBVET, Londrina, V. 6, N. 26, Ed. 213, Art. 1420, 2012.

O comportamento natural da água, no tocante a sua ocorrência, transformações de estado e relações com a vida humana, é bem caracterizado através do conceito de ciclo hidrológico (FUNASA, 2003).

O ciclo da água, também denominado ciclo hidrológico, é responsável pela renovação da água no planeta. O ciclo da água inicia-se com a energia solar, incidente no planeta Terra, que é responsável pela evapotranspiração das águas dos rios, reservatórios e mares, bem como pela transpiração das plantas. As forças da natureza são responsáveis pelo ciclo da água. A água é fator decisivo para que a vida surgisse e se desenvolvesse na Terra. O vapor d'água forma as nuvens, cuja movimentação sofre influência do movimento de rotação da Terra e das correntes atmosféricas. A condensação do vapor d'água forma as chuvas. Quando a água das chuvas atinge a terra, ocorrem dois fenômenos: um deles consiste no seu escoamento superficial em direção aos canais de menor declividade, alimentando diretamente os rios e o outro, a infiltração no solo, alimentando os lençóis subterrâneos. A água dos rios tem como destino final os mares e, assim, fechando o ciclo das águas (CETESB, 2008). A movimentação da água na natureza é mostrada na figura 2 a seguir.

O volume total da água permanece constante no planeta, sendo estimado em torno de 1,5 bilhão de quilômetros cúbicos. Os oceanos constituem cerca de $97,5 \%$ de toda a água do planeta. Dos 2,5\% restantes, aproximadamente $1,9 \%$ estão localizados nas calotas polares e nas geleiras, enquanto apenas $0,6 \%$ é encontrado na forma de água subterrânea, em lagos, rios e também na atmosfera, como vapor d'água (ibid.).

Em linhas gerais, o ciclo hidrológico compõe-se das seguintes etapas: precipitação, infiltração, escoamento e evaporação. Da água que chega à terra uma parte cai diretamente sobre as superfícies aquáticas, outra escoa sobre o solo e vai até os rios, lagos e oceanos; parte retorna de imediato à atmosfera por evaporação ou evapotranspiração da vegetação e parte se infiltra no solo (FUNASA, 2003). 
PRAXEDES, C.I.S., CARRIJO, K.F., FREIRE, R.G.S. Controle físico-químico de água de abastecimento para consumo e uso industrial: sistema de tratamento, métodos de análise e parâmetros legais. PUBVET, Londrina, V. 6, N. 26, Ed. 213, Art. 1420, 2012.

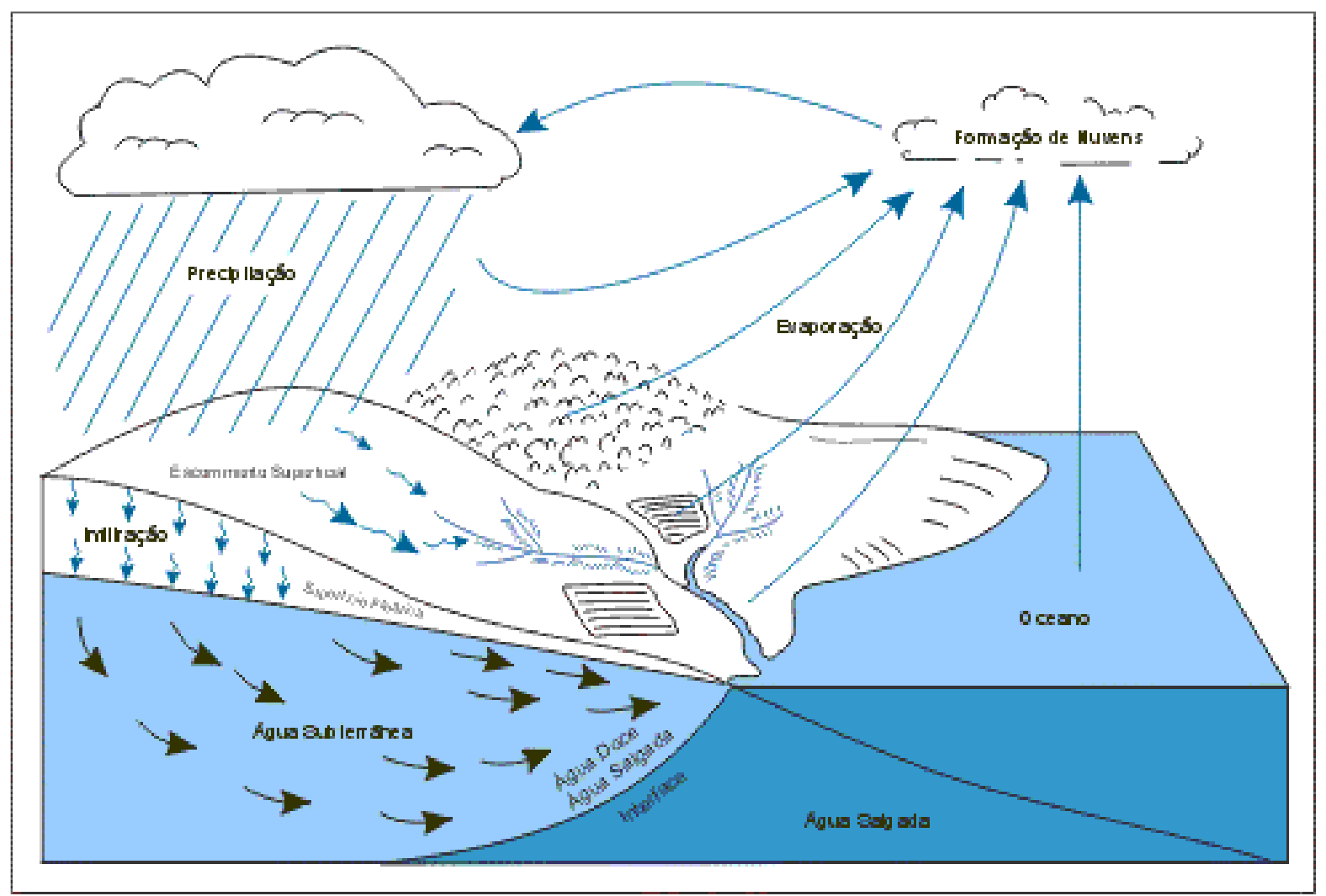

Figura 2. Ciclo Hidrológico

Fonte: Heat, R. Hidrologia Básica de Águas Subterrâneas. United States Geological Survey Water Supply Paper 2220.

\subsection{NECESSIDADE DE IMPLANTAÇÃO DE SISTEMA DE ABASTECIMENTO DE ÁGUA}

A água é necessária para diversas finalidades entre as quais as de uso doméstico como beber e cozinhar e usos industriais diversos.

Nas zonas rurais, onde a densidade populacional é pequena, todas as necessidades podem ser satisfeitas mediante a escavação ou a perfuração de poços ou armazenamento em cisternas da água de chuva.

Nas zonas urbanas onde a densidade populacional é maior, essas fontes de abastecimento nem sempre são suficientes para atender as necessidades de consumo e é preciso recorrer a lagos, rios, represas, etc. 
PRAXEDES, C.I.S., CARRIJO, K.F., FREIRE, R.G.S. Controle físico-químico de água de abastecimento para consumo e uso industrial: sistema de tratamento, métodos de análise e parâmetros legais. PUBVET, Londrina, V. 6, N. 26, Ed. 213, Art. 1420, 2012.

Em contra partida a utilização dessa água em grande quantidade irá possibilitar a poluição dos mananciais locais, através do lançamento dos despejos, tornando-a inadequada ao consumo humano. Desta forma, a importância do abastecimento de água deve ser encarada sob os aspectos sanitário e econômico e sua qualidade e quantidade, a ser utilizada no sistema, está intimamente relacionada às características do manancial (FUNASA, 2003).

\subsection{TRATAMENTO DA ÁGUA}

Um sistema de abastecimento de água compreende obras e equipamentos capazes de captar, condicionar convenientemente, transportar, acumular e distribuir a água, que se encontra nos principais mananciais, aos consumidores (população).

São as seguintes fases de um sistema de abastecimento de água:

Captação: Tomada d'água. Obras, equipamentos e canalizações destinadas a retirar água da fonte de suprimento.

Adução: Obras, equipamentos e canalizações para transporte de água bruta ou de água tratada.

Tratamento: Obras, equipamentos e canalizações para purificação da água.

Acumulação ou Reservação: Obras, equipamentos e canalizações para reservar água a fim de distribuí-la para os centros de consumo.

Distribuição: Obras, equipamentos e canalizações destinadas a distribuir a água aos centros de consumo (FUNASA, 2003).

Para que possa ser consumida, sem apresentar riscos à saúde, ou seja, tornar-se potável, a água tem que ser tratada, limpa e descontaminada.

O sistema de tratamento e produção de água potável é um conjunto de estruturas, equipamentos e instrumentos destinados a produzir água de consumo humano a fim de entregá-la aos usuários em quantidade e qualidade adequadas, de forma continuada e a um custo acessível (QUIMICA AMBIENTAL, 2008). Os sistemas de abastecimento de água geralmente contêm 
PRAXEDES, C.I.S., CARRIJO, K.F., FREIRE, R.G.S. Controle físico-químico de água de abastecimento para consumo e uso industrial: sistema de tratamento, métodos de análise e parâmetros legais. PUBVET, Londrina, V. 6, N. 26, Ed. 213, Art. 1420, 2012.

os seguintes componentes: obras de captação, estação de tratamento, redes de distribuição e conexões domiciliares.

Produzir água potável não é fácil. Requer investimento de grandes cifras para construir estações de tratamento e comprar os insumos necessários para purificá-la. A qualidade da água tratada depende do seu uso. É de vital importância para a saúde pública que a comunidade conte com um abastecimento seguro que satisfaça as necessidades domésticas tais como o consumo, à preparação de alimentos e à higiene pessoal (FUNASA, 2003).

Para alcançar este propósito devem ser atendidas uma série de normas de qualidade (física, química e microbiológica), de tal maneira que a água esteja livre de organismos capazes de originar enfermidades e de qualquer mineral, substância química ou orgânica que possa prejudicar a saúde (ibid).

Quase toda água potável que consumimos se transforma em esgoto que é reintroduzido nos rios e lagos. Estes mananciais, uma vez contaminados, podem conter microrganismos causadores de várias doenças como a diarreia, hepatite, cólera e febre tifoide. Além dos microrganismos, as águas dos rios e lagos contêm muitas partículas que também precisam ser removidas antes do consumo humano. Daí a necessidade de se tratar a água para que esta volte a ser propícia para o consumo humano (ibid).

Quando se pensa em água tratada normalmente vem à mente o tratamento de uma água que estava poluída, como o esgoto, para uma que volte a ser limpa. Cabe aqui fazer uma distinção entre tratamento de água e tratamento de esgoto: o tratamento de água é feito a partir da água doce encontrada na natureza que contém resíduos orgânicos, sais dissolvidos, metais pesados, partículas em suspensão e microrganismos. Por essa razão a água é levada do manancial para a Estação de Tratamento de Água (ETA), conforme se observa na Figura 1. 
PRAXEDES, C.I.S., CARRIJO, K.F., FREIRE, R.G.S. Controle físico-químico de água de abastecimento para consumo e uso industrial: sistema de tratamento, métodos de análise e parâmetros legais. PUBVET, Londrina, V. 6, N. 26, Ed. 213, Art. 1420, 2012.

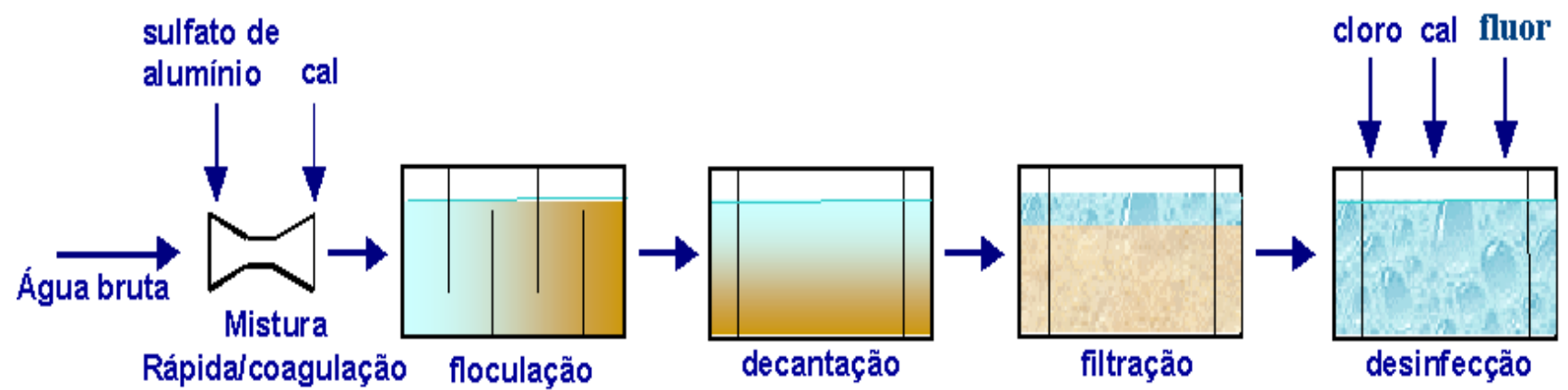

Figura 3 Esquema da ETA

Fonte: FUNASA, 2003.

Já o tratamento de esgoto é feito a partir de esgotos residenciais ou industriais para, após o tratamento, a água poder ser re-introduzida no rio minimizando seu impacto ao ambiente (FUNASA, 2003).

Podemos dividir o tratamento de água de mananciais em duas etapas, as quais chamamos de tratamento inicial e tratamento final.

\subsubsection{TRATAMENTO INICIAL}

Não há reações químicas envolvidas, somente processos físicos. PENEIRAMENTO: elimina as sujeiras maiores.

SEDIMENTAÇÃO OU DECANTAÇÃO: pedaços de impurezas que não foram retirados com o peneiramento são depositados no fundo dos tanques.

A sedimentação simples é adequada apenas para águas relativamente puras, que contém pequena quantidade de sólidos em suspensão, sendo este procedimento realizado em fluxo contínuo.

AERAÇÃO: borbulha-se ar com o intuito de retirar substâncias responsáveis pelo mau cheiro da água (ácido sulfídrico, substâncias voláteis, etc).

\subsubsection{TRATAMENTO FINAL}

COAGULAÇÃO OU FLOCULAÇÃO: neste processo as partículas sólidas se aglomeram em flocos para que sejam removidas mais facilmente. $\mathrm{O} \mathrm{pH}$ da 
PRAXEDES, C.I.S., CARRIJO, K.F., FREIRE, R.G.S. Controle físico-químico de água de abastecimento para consumo e uso industrial: sistema de tratamento, métodos de análise e parâmetros legais. PUBVET, Londrina, V. 6, N. 26, Ed. 213, Art. 1420, 2012.

água tem que ser elevado pela adição ou de uma base diretamente, ou de um sal básico conhecido como barrilha (carbonato de sódio): A água recebe uma substância química (sulfato de alumínio ou cobre, cloreto férrico). Este produto faz com que as impurezas se aglutinem formando flocos para serem facilmente removidos ( $\mathrm{pH} 8,5-11)$.

A floculação consiste na formação e precipitação de hidróxido de alumínio $\left(\mathrm{Al}_{2}(\mathrm{OH})_{3}\right)$ que é insolúvel em água e "carrega" as impurezas para o fundo do tanque.

base:

$\mathrm{NaOH}_{(\mathrm{s}) \rightarrow \mathrm{Na}^{+}}{ }_{(\mathrm{aq})}+\mathrm{OH}^{-}(\mathrm{aq})$

sal básico:

$\mathrm{Na}_{2} \mathrm{CO}_{3}(\mathrm{~s}) \rightarrow 2 \mathrm{Na}^{+}{ }_{(\mathrm{aq})}+\mathrm{CO}_{3}{ }^{2-}{ }_{(\mathrm{aq})}$

$\mathrm{CO}_{3}{ }^{2-}{ }_{(\mathrm{aq})}+\mathrm{H}_{2} \mathrm{O}_{(\mathrm{I})} \rightarrow \mathrm{HCO}_{3}^{-}{ }_{(\mathrm{aq})}+\mathrm{OH}_{(\mathrm{aq})}^{-}$

Após o ajuste do $\mathrm{pH}$, adiciona-se o sulfato de alumínio, que irá dissolver na água e depois precipitar na forma de hidróxido de alumínio.

Concentrações de substâncias químicas utilizadas na floculação:

1. Sulfato de alumínio

É usado em doses de 15 a $1000 \mathrm{mg} / \mathrm{L}$, dependendo da turbidez da água, do reativo comercial.

$\mathrm{Al}_{2}\left(\mathrm{SO}_{4}\right)_{3}+18 \mathrm{H}_{2} \mathrm{O}$.

$\mathrm{Al}_{2}\left(\mathrm{SO}_{4}\right)_{3}+3 \mathrm{Ca}\left(\mathrm{HCO}_{3}\right)_{2} 3 \mathrm{CaSO}_{4}+2 \mathrm{Al}(\mathrm{OH})_{3}+6 \mathrm{CO}_{2}$

2. Cloreto férrico

É usado em doses de 5 a $100 \mathrm{mg} / \mathrm{L}$ de cloreto férrico comercial $\mathrm{FeCl}+6 \mathrm{H}_{2} \mathrm{O}$, de acordo com a turbidez da água.

$2 \mathrm{FeCl}_{3}+3 \mathrm{Ca}\left(\mathrm{HCO}_{3}\right)_{2} 3 \mathrm{CaCl}_{2}+2 \mathrm{Fe}(\mathrm{OH})_{3}+6 \mathrm{CO}_{2}$ 
PRAXEDES, C.I.S., CARRIJO, K.F., FREIRE, R.G.S. Controle físico-químico de água de abastecimento para consumo e uso industrial: sistema de tratamento, métodos de análise e parâmetros legais. PUBVET, Londrina, V. 6, N. 26, Ed. 213, Art. 1420, 2012.

\section{Sulfato férrico}

É usado em doses de 10 a $50 \mathrm{mg} / \mathrm{L}$ de sulfato de ferro comercial Fe2(SO4)3. $9 \mathrm{H}_{2} \mathrm{O}$, dependendo da turbidez da água.

$\mathrm{Fe} 2(\mathrm{SO} 4) 3+3 \mathrm{Ca}\left(\mathrm{HCO}_{3}\right) 22 \mathrm{Fe}(\mathrm{OH}) 3+3 \mathrm{CaSO}_{4}+6 \mathrm{CO}_{2}$

$>$ Dissolução

$\mathrm{Al}_{2}\left(\mathrm{SO}_{4}\right)_{3(\mathrm{~s}) \rightarrow} 2 \mathrm{Al}^{3+}{ }_{(\mathrm{aq})}+2 \mathrm{SO}_{4}{ }^{3-}{ }_{(\mathrm{aq})}$

$>$ Precipitação

$\mathrm{Al}^{3+}{ }_{(\mathrm{aq})}+3 \mathrm{OH}_{(\mathrm{aq})}^{-} \rightarrow \mathrm{Al}(\mathrm{OH})_{3(\mathrm{~s})}$

Facilitando esta precipitação, o sistema de paletas no tanque de floculação age como uma barreira física para as impurezas da água. Estes flocos dispersos na água ao chocarem-se com uma paleta sedimentam no fundo do tanque. Facilitando esta ação física, a vazão da água de entrada no tanque é maior que a da água de saída.

SEDIMENTAÇÃO OU DECANTAÇÃO: os flocos formados vão sedimentando no fundo do tanque "limpando" a água. Remove de 85 a 95\% de substâncias sedimentáveis.

FILTRAÇÃO: a água da parte superior do tanque de sedimentação passa por um filtro que contém várias camadas de cascalho e areia, e assim retiram as impurezas menores. Os filtros podem ser de granulação com areia e carvão ou de esponja.

A filtração pode ser rápida ou lenta em um processo de tratamento da água. A principal diferença não é simplesmente a velocidade de filtração, porém o conceito base do processo. A filtração lenta é essencialmente um processo biológico enquanto que a filtração rápida é um processo físico (FUNASA, 2003).

Os filtros lentos têm como vantagem sobre os filtros rápidos a sua produção de uma água bacteriologicamente "limpa" na qual não requer 
PRAXEDES, C.I.S., CARRIJO, K.F., FREIRE, R.G.S. Controle físico-químico de água de abastecimento para consumo e uso industrial: sistema de tratamento, métodos de análise e parâmetros legais. PUBVET, Londrina, V. 6, N. 26, Ed. 213, Art. 1420, 2012.

desinfecção para a inativação de bactéria, embora a adição do desinfetante não pode ser descartada em razão da necessidade de existir o cloro residual dentro das águas que são distribuídas pela rede. Entretanto, em função da sua baixa taxa de filtração, os filtros lentos requerem grandes áreas na implantação de atendimento para populações maiores e necessitam de muito volume de trabalho na sua operação e manutenção. Para o restabelecimento da camada de "schumtzdecke" do filtro requer alguns dias, e desta forma existe a necessidade da ETA ter capacidade suficiente para produzir a demanda de água com apenas um filtro em operação (ibid).

Os filtros rápidos são comumente utilizados em todo o mundo e são mais populares do que os filtros lentos. O principal fator de decisão é a utilização de pouca área e custos de compatíveis de implantação. Entretanto, os filtros rápidos não produzem a mesma qualidade de água do filtro lento e estão afastados da eficiência para destruição das bactérias do mesmo, necessitando de medidas de desinfecção mais apuradas. Os filtros rápidos não tem a eficiência para a remoção de vírus (ibid).

DESINFECÇÃO: é adicionado na água um composto bactericida e fungicida, como por exemplo, o hipoclorito de sódio (água sanitária, $\mathrm{NaClO}$ ), conhecido como 'cloro'. Este é aplicado na forma de gás na água na proporção de 1 a 4 kg por 25.000 litros. A eficiência do cloro depende do $\mathrm{pH}$, da temperatura da água e da concentração de matéria orgânica e minerais indesejáveis. O cloro é um agente oxidante que atua diretamente bloqueando as enzimas bacterianas que oxidam a glicose, como a triose-fosfórico-desidrogenase. $\mathrm{O} \mathrm{pH}$ constitui um dos mais importantes fatores que influem na cloração da água, independentemente da sua forma de emprego. A forma de ácido hipocloroso é a mais ativa sendo a faixa de $\mathrm{pH}$ ideal entre 6 e 8,5 (FUNASA, 2003). 
PRAXEDES, C.I.S., CARRIJO, K.F., FREIRE, R.G.S. Controle físico-químico de água de abastecimento para consumo e uso industrial: sistema de tratamento, métodos de análise e parâmetros legais. PUBVET, Londrina, V. 6, N. 26, Ed. 213, Art. 1420, 2012.

\subsection{IMPORTÂNCIA DA ANÁLISE FÍSICO-QUÍMICA DE ÁGUA E RESÍDUOS}

A água geralmente é aceita como potável quando está de acordo com padrões microbiológicos e físico-químicos estabelecidos pela Portaria n518, de 25 de março de 2004 (BRASIL, 2004). Critérios de qualidade da água usada para ingestão, ou para os diversos usos nas plantas de processamento de alimentos, são necessários para evitar riscos à saúde do consumidor e reduzir efeitos indesejáveis nas instalações e nos processamentos como corrosão, formação de depósitos ou sedimentos (PORETTI, 1990 apud MÁRSICO; MANO, 2008)

Portanto, analisar e verificar o padrão de potabilidade da água para os diversos fins de interesse preconiza sua melhor utilização, evitando problemas sanitários e econômicos.

\subsection{NORMAS DE COLETA DE AMOSTRAS}

A coleta da amostra constitui a primeira fase da análise do produto. Dentro do conceito de que a análise começa com a coleta da amostra, o serviço de coleta deve ser bem integrado com o laboratório, devendo haver sincronismo entre a remessa e a capacidade do laboratório em executar as análises $^{1}$. A seguir serão abordadas algumas medidas a serem adotadas quanto à coleta de amostras para análise de água, conforme Brasil (1981).

- As amostras para exames físico-químicos deverão ser enviadas separadas daquelas destinadas a exame microbiológico;

- As amostras para exames físico-químico deverão ser acondicionadas em recipientes limpos e íntegros (sem perfurações, rachaduras, etc.);

\footnotetext{
${ }^{1}$ PORETTI, M. Quality control of water as raw material in the food industry. Food Control, v.1, n.3, p. 79-93, 1990.
} 
PRAXEDES, C.I.S., CARRIJO, K.F., FREIRE, R.G.S. Controle físico-químico de água de abastecimento para consumo e uso industrial: sistema de tratamento, métodos de análise e parâmetros legais. PUBVET, Londrina, V. 6, N. 26, Ed. 213, Art. 1420, 2012.

- Em casos especiais, a amostra poderá ser acompanhada de relatório adicional, contendo informações que possam auxiliar o analista na condução do seu trabalho;

- Somente serão aceitas pelo laboratório as amostras que vierem acompanhadas de indicação precisa do(s) tipo(s) de exame(s) a ser(em) realizado(s);

- Depois de coletadas, as amostras deverão ser acondicionadas adequadamente, para evitar qualquer alteração nas mesmas até sua chegada ao laboratório. Assim, as amostras de produtos facilmente alteráveis deverão ser acondicionadas em recipientes isotérmicos, e acompanhadas de gelo ou outra substância refrigerante, cuidando-se sempre para que não haja contatos deste com a amostra;

- Providências especiais deverão ser tomadas para que o tempo decorrido entre a coleta da amostra e sua chegada ao laboratório seja o mais breve possível, recomendando-se que seja evitada a utilização de mecanismos que impliquem em estocagem intermediária entre 0 ponto de coleta e 0 laboratório;

- Somente serão aceitas para análise, amostras que houverem sido acondicionadas em embalagem lacrada pela pessoa que efetuou a coleta, sugerindo-se, para tal, a utilização de lacre ou outro tipo de fechamento hermético, que não possa ser violado sem que se torne evidente. Tal providência se faz necessária para evitar a substituição ou adulteração da amostra entre o ponto da colheita e o laboratório, com reflexos no resultado da análise;

- Todas as amostras que chegarem ao laboratório em condições diferentes das aqui preconizadas, serão recusadas, cabendo ao laboratório notificar, à pessoa que realizou a coleta, a razão da não aceitação (BRASIL, 1981). 
PRAXEDES, C.I.S., CARRIJO, K.F., FREIRE, R.G.S. Controle físico-químico de água de abastecimento para consumo e uso industrial: sistema de tratamento, métodos de análise e parâmetros legais. PUBVET, Londrina, V. 6, N. 26, Ed. 213, Art. 1420, 2012.

\subsection{LEGISLAÇÃO}

No que tange à água de consumo humano, existem, em termos de legislação, um conjunto de valores máximos permissíveis das características físico-químicas e bacteriológicas, baseados em estudos toxicológicos resultantes da exposição do organismo aos agentes presentes na água e que constituem em fator de risco para a saúde humana.

As normas e o padrão são estabelecidos pelas autoridades sanitárias dos países por meio de leis, decretos ou regulamentos e podem variar de acordo com as condições de cada país. Utilizam-se como referência os valores definidos pela Organização Mundial de Saúde (OMS), que não tem caráter obrigatório e podem ser modificados pela autoridade sanitária do país segundo suas variáveis locais e/ou regionais relacionadas com aspectos econômicos, ambientais e sociais. A OMS estabelece esse padrão (OPAS, 1995) através da avaliação de risco dos contaminantes físico-químicos, microbiológicos e radiológicos que não necessariamente estão presentes em sua totalidade em todos os Sistemas de Abastecimento de Água (SAA). Por essa razão, segundo a OMS, ao estabelecer padrão de potabilidade, cada país deve realizar estudos criteriosos levando em consideração suas características hidrogeológicas e as atividades humanas desenvolvidas em seu território priorizando a proteção da saúde coletiva (LIRA, 2000).

$\mathrm{Na}$ Comunidade Européia Integrada, no qual fazem parte quinze países membros, encontramos a Diretiva n. ${ }^{\circ}$ 80/776/EC- Quality of water intend for humam consumption (EEC, 1980), que estabelece os parâmetros de referência mínimos, além de apresentar as frequências mínimas de amostragem para regulamentação em cada país membro pela autoridade nacional competente. Cada país pode estabelecer valores mais exigentes. Esta Diretiva está em vias de ser revisada para incorporar as inovações cientificas desde os anos 80, devendo ser dividida em parâmetros microbiológicos, químicos e indicadores, sendo que o parâmetro indicador representará o "gatilho" no que refere a 
PRAXEDES, C.I.S., CARRIJO, K.F., FREIRE, R.G.S. Controle físico-químico de água de abastecimento para consumo e uso industrial: sistema de tratamento, métodos de análise e parâmetros legais. PUBVET, Londrina, V. 6, N. 26, Ed. 213, Art. 1420, 2012.

mudança da qualidade da água de consumo para iniciar a ação da saúde pública (FERREIRA JúNIOR, 2002).

No Brasil, as normas e o padrão de potabilidade são regulamentados através de Portaria do Ministério da Saúde, que estabelece níveis máximos permitidos para as características da água de consumo humano, os quais devem ser observados em todo o território nacional. A primeira norma e padrão de potabilidade nacional - Portaria n. ${ }^{\circ}$ 57/Bsb - foi estabelecida em 1977, a segunda norma - Portaria n.036/90, a terceira norma de potabilidade Portaria n. ${ }^{01469}$, de 29 de dezembro de 2000 e atualmente a Portaria n518, de 25 de março de 2004 (ibid.).

Todas as Portarias referentes às normas e padrão de potabilidade de água, foram oriundas do Decreto n.079.367, de 9 de março de 1977, que autorizou o Ministério da Saúde a estabelecer o padrão "... a serem observados em todo o território nacional.", assim como determinava em seus artigos a fiscalização e controle da norma, a indicação para financiamento à melhoria dos serviços de controle de qualidade da água e a capacitação de recursos humanos (ibid.).

De acordo com a Portaria do Ministério da Saúde n518, de 25 de março de 2004, a água potável deve estar em conformidade com o padrão microbiológico, de turbidez, de substâncias químicas que representam risco à saúde, de radioatividade e de aceitação para consumo humano, conforme os quadros 3, 4, 5, 6 e 7 apresentados a seguir. 
PRAXEDES, C.I.S., CARRIJO, K.F., FREIRE, R.G.S. Controle físico-químico de água de abastecimento para consumo e uso industrial: sistema de tratamento, métodos de análise e parâmetros legais. PUBVET, Londrina, V. 6, N. 26, Ed. 213, Art. 1420, 2012.

Quadro 3. Padrão microbiológico de potabilidade da água para consumo humano

\begin{tabular}{|c|c|}
\hline PARÂMETRO & $\mathrm{VMP}^{(1)}$ \\
\hline \multicolumn{2}{|c|}{ Água para consumo humano(2) } \\
\hline $\begin{array}{l}\text { Escherichia coli ou coliformes } \\
\text { termotolerantes }{ }^{(3)}\end{array}$ & Ausência em 100 mL \\
\hline \multicolumn{2}{|c|}{ Água na saída do tratamento } \\
\hline Coliformes totais & Ausência em 100 mL \\
\hline \multicolumn{2}{|c|}{ Água tratada no sistema de distribuição (reservatórios e rede) } \\
\hline $\begin{array}{c}\text { Escherichia coli ou coliformes } \\
\text { termotolerantes }{ }^{(3)}\end{array}$ & Ausência em 100 mL \\
\hline \multirow[t]{4}{*}{ Coliformes totais } & Sistemas que analisam 40 ou mais amostras por mês: \\
\hline & $\begin{array}{c}\text { Ausência em } 100 \mathrm{~mL} \text { em } 95 \% \text { das amostras examinadas } \\
\text { no mês; }\end{array}$ \\
\hline & Sistemas que analisam menos de 40 amostras por mês: \\
\hline & $\begin{array}{c}\text { Apenas uma amostra poderá apresentar mensalmente } \\
\text { resultado positivo em } 100 \mathrm{~mL}\end{array}$ \\
\hline
\end{tabular}

NOTAS:

${ }^{(1)}$ Valor Máximo Permitido.

(2) água para consumo humano em toda e qualquer situação, incluindo fontes individuais como poços, minas, nascentes, dentre outras.

(3) A detecção de Escherichia coli deve ser preferencialmente adotada.

FONTE: BRASIL (2004)

Quadro 4. Padrão de turbidez para água pós-filtração ou pré-desinfecção

\begin{tabular}{|c|c|}
\hline TRATAMENTO DA ÁGUA & VMP $^{(1)}$ \\
\hline Desinfecção (água subterrânea) & $1,0 \mathrm{UT}^{(2)}$ em 95\% das amostras \\
\hline $\begin{array}{c}\text { Filtração rápida (tratamento completo ou } \\
\text { filtração direta) }\end{array}$ & $1,0 \mathrm{UT}^{(2)}$ \\
\hline Filtração lenta & $2,0 \mathrm{UT}^{(2)}$ em 95\% das amostras \\
\hline
\end{tabular}

NOTAS:

${ }^{(1)}$ Valor máximo permitido.

(2) Unidade de turbidez.

FONTE: BRASIL (2004) 
PRAXEDES, C.I.S., CARRIJO, K.F., FREIRE, R.G.S. Controle físico-químico de água de abastecimento para consumo e uso industrial: sistema de tratamento, métodos de análise e parâmetros legais. PUBVET, Londrina, V. 6, N. 26, Ed. 213, Art. 1420, 2012.

Quadro 5. Padrão de potabilidade para substâncias químicas que representam risco à saúde

\begin{tabular}{|c|c|c|}
\hline PARÂMETRO & Unidade & $\mathrm{VMP}^{(1)}$ \\
\hline \multicolumn{3}{|l|}{ INORGÂNICAS } \\
\hline Antimônio & $\mathrm{mg} / \mathrm{L}$ & 0,005 \\
\hline Arsênio & $\mathrm{mg} / \mathrm{L}$ & 0,01 \\
\hline Bário & $\mathrm{mg} / \mathrm{L}$ & 0,7 \\
\hline Cádmio & $\mathrm{mg} / \mathrm{L}$ & 0,005 \\
\hline Cianeto & $\mathrm{mg} / \mathrm{L}$ & 0,07 \\
\hline Chumbo & $\mathrm{mg} / \mathrm{L}$ & 0,01 \\
\hline Cobre & $\mathrm{mg} / \mathrm{L}$ & 2 \\
\hline Cromo & $\mathrm{mg} / \mathrm{L}$ & 0,05 \\
\hline Fluoreto $^{(2)}$ & $\mathrm{mg} / \mathrm{L}$ & 1,5 \\
\hline Mercúrio & $\mathrm{mg} / \mathrm{L}$ & 0,001 \\
\hline Nitrato (como N) & $\mathrm{mg} / \mathrm{L}$ & 10 \\
\hline Nitrito (como N) & $\mathrm{mg} / \mathrm{L}$ & 1 \\
\hline Selênio & $\mathrm{mg} / \mathrm{L}$ & 0,01 \\
\hline \multicolumn{3}{|l|}{ ORGÂNICAS } \\
\hline Acrilamida & $\mu \mathrm{g} / \mathrm{L}$ & 0,5 \\
\hline Benzeno & $\mu \mathrm{g} / \mathrm{L}$ & 5 \\
\hline Benzo[a]pireno & $\mu \mathrm{g} / \mathrm{L}$ & 0,7 \\
\hline Cloreto de Vinila & $\mu \mathrm{g} / \mathrm{L}$ & 5 \\
\hline 1,2 Dicloroetano & $\mu \mathrm{g} / \mathrm{L}$ & 10 \\
\hline 1,1 Dicloroeteno & $\mu g / L$ & 30 \\
\hline Diclorometano & $\mu \mathrm{g} / \mathrm{L}$ & 20 \\
\hline Estireno & $\mu \mathrm{g} / \mathrm{L}$ & 20 \\
\hline Tetracloreto de Carbono & $\mu \mathrm{g} / \mathrm{L}$ & 2 \\
\hline Tetracloroeteno & $\mu \mathrm{g} / \mathrm{L}$ & 40 \\
\hline Triclorobenzenos & $\mu \mathrm{g} / \mathrm{L}$ & 20 \\
\hline Tricloroeteno & $\mu \mathrm{g} / \mathrm{L}$ & 70 \\
\hline \multicolumn{3}{|l|}{ AGROTÓXICOS } \\
\hline Alaclor & $\mu \mathrm{g} / \mathrm{L}$ & 20,0 \\
\hline Aldrin e Dieldrin & $\mu \mathrm{g} / \mathrm{L}$ & 0,03 \\
\hline Atrazina & $\mu \mathrm{g} / \mathrm{L}$ & 2 \\
\hline Bentazona & $\mu \mathrm{g} / \mathrm{L}$ & 300 \\
\hline Clordano (isômeros) & $\mu \mathrm{g} / \mathrm{L}$ & 0,2 \\
\hline $2,4 \mathrm{D}$ & $\mu \mathrm{g} / \mathrm{L}$ & 30 \\
\hline DDT (isômeros) & $\mu \mathrm{g} / \mathrm{L}$ & 2 \\
\hline Endossulfan & $\mu \mathrm{g} / \mathrm{L}$ & 20 \\
\hline Endrin & $\mu \mathrm{g} / \mathrm{L}$ & 0,6 \\
\hline Glifosato & $\mu \mathrm{g} / \mathrm{L}$ & 500 \\
\hline Heptacloro e Heptacloro epóxido & $\mu \mathrm{g} / \mathrm{L}$ & 0,03 \\
\hline Hexaclorobenzeno & $\mu \mathrm{g} / \mathrm{L}$ & 1 \\
\hline Lindano (g-BHC) & $\mu \mathrm{g} / \mathrm{L}$ & 2 \\
\hline Metolacloro & $\mu \mathrm{g} / \mathrm{L}$ & 10 \\
\hline
\end{tabular}


PRAXEDES, C.I.S., CARRIJO, K.F., FREIRE, R.G.S. Controle físico-químico de água de abastecimento para consumo e uso industrial: sistema de tratamento, métodos de análise e parâmetros legais. PUBVET, Londrina, V. 6, N. 26, Ed. 213, Art. 1420, 2012.

\begin{tabular}{|c|c|c|}
\hline Metoxicloro & $\mu \mathrm{g} / \mathrm{L}$ & 20 \\
\hline Molinato & $\mu \mathrm{g} / \mathrm{L}$ & 6 \\
\hline Pendimetalina & $\mu \mathrm{g} / \mathrm{L}$ & 20 \\
\hline Pentaclorofenol & $\mu \mathrm{g} / \mathrm{L}$ & 9 \\
\hline Permetrina & $\mu \mathrm{g} / \mathrm{L}$ & 20 \\
\hline Propanil & $\mu \mathrm{g} / \mathrm{L}$ & 20 \\
\hline Simazina & $\mu \mathrm{g} / \mathrm{L}$ & 2 \\
\hline Trifluralina & $\mu \mathrm{g} / \mathrm{L}$ & 20 \\
\hline \multicolumn{3}{|c|}{ CIANOTOXINAS } \\
\hline Microcistinas $^{(3)}$ & $\mu \mathrm{g} / \mathrm{L}$ & 1,0 \\
\hline \multicolumn{3}{|c|}{ DESINFETANTES E PRODUTOS SECUNDÁRIOS DA DESINFECÇÃC } \\
\hline \begin{tabular}{|c|} 
Bromato \\
\end{tabular} & $\mathrm{mg} / \mathrm{L}$ & 0,025 \\
\hline Clorito & $\mathrm{mg} / \mathrm{L}$ & 0,2 \\
\hline Cloro livre $^{(4)}$ & $\mathrm{mg} / \mathrm{L}$ & 5 \\
\hline Monocloramina & $\mathrm{mg} / \mathrm{L}$ & 3 \\
\hline $2,4,6$ Triclorofenol & $\mathrm{mg} / \mathrm{L}$ & 0,2 \\
\hline Trihalometanos Total & $\mathrm{mg} / \mathrm{L}$ & 0,1 \\
\hline
\end{tabular}

NOTAS:

(1) Valor Máximo Permitido.

${ }^{(2)}$ Os valores recomendados para a concentração de íon fluoreto devem observar à legislação específica vigente relativa à fluoretação da água, em qualquer caso devendo ser respeitado o VMP desta Tabela.

(3) É aceitável a concentração de até $10 \mu \mathrm{g} / \mathrm{L}$ de microcistinas em até 3 (três) amostras, consecutivas ou não, nas análises realizadas nos últimos 12 (doze) meses.

${ }^{(4)}$ Análise exigida de acordo com o desinfetante utilizado.

FONTE: BRASIL (2004)

Quadro 6. Padrão de radioatividade para água potável

\begin{tabular}{|c|c|c|}
\hline Parâmetro & Unidade & VMP $^{(1)}$ \\
\hline Radioatividade alfa global & $\mathrm{Bq} / \mathrm{L}$ & $0,1^{(2)}$ \\
\hline Radioatividade beta global & $\mathrm{Bq} / \mathrm{L}$ & $1,0^{(2)}$ \\
\hline
\end{tabular}

NOTAS:

${ }^{(1)}$ Valor máximo permitido.

${ }^{(2)}$ Se os valores encontrados forem superiores aos VMP, deverá ser feita a identificação dos radionuclídeos presentes e a medida das concentrações respectivas. Nesses casos, deverão ser aplicados, para os radionuclídeos encontrados, os valores estabelecidos pela legislação pertinente da Comissão Nacional de Energia Nuclear - CNEN, para se concluir sobre a potabilidade da água.

FONTE: BRASIL (2004) 
PRAXEDES, C.I.S., CARRIJO, K.F., FREIRE, R.G.S. Controle físico-químico de água de abastecimento para consumo e uso industrial: sistema de tratamento, métodos de análise e parâmetros legais. PUBVET, Londrina, V. 6, N. 26, Ed. 213, Art. 1420, 2012.

Quadro 7. Padrão de aceitação para consumo humano

\begin{tabular}{|l|l|l|}
\hline PARÂMETRO & Unidade & VMP(1) \\
\hline Alumínio & $\mathrm{mg} / \mathrm{L}$ & 0,2 \\
\hline Amônia $\left(\right.$ como $\left.\mathrm{NH}_{3}\right)$ & $\mathrm{mg} / \mathrm{L}$ & 1,5 \\
\hline Cloreto & $\mathrm{mg} / \mathrm{L}$ & 250 \\
\hline Cor Aparente & $\mathrm{uH}(2)$ & 15 \\
\hline Dureza & $\mathrm{mg} / \mathrm{L}$ & 500 \\
\hline Etilbenzeno & $\mathrm{mg} / \mathrm{L}$ & 0,2 \\
\hline Ferro & $\mathrm{mg} / \mathrm{L}$ & 0,3 \\
\hline Manganês & $\mathrm{mg} / \mathrm{L}$ & 0,1 \\
\hline Monoclorobenzeno & $\mathrm{mg} / \mathrm{L}$ & 0,12 \\
\hline Odor & - & Não objetável(3) \\
\hline Gosto & - & Não objetável \\
\hline Sódio & $\mathrm{mg} / \mathrm{L}$ & 200 \\
\hline Sólidos dissolvidos totais & $\mathrm{mg} / \mathrm{L}$ & 1.000 \\
\hline Sulfato & $\mathrm{mg} / \mathrm{L}$ & 250 \\
\hline Sulfeto de Hidrogênio & $\mathrm{mg} / \mathrm{L}$ & 0,05 \\
\hline Surfactantes & $\mathrm{mg} / \mathrm{L}$ & 0,5 \\
\hline Tolueno & $\mathrm{mg} / \mathrm{L}$ & 0,17 \\
\hline Turbidez & UT/(4) & 5 \\
\hline Zinco & $\mathrm{mg} / \mathrm{L}$ & 5 \\
\hline Xileno & $\mathrm{mg} / \mathrm{L}$ & 0,3 \\
\hline
\end{tabular}

FONTE: BRASIL (2004)

$\S 10$ Recomenda-se que, no sistema de distribuição, o pH da água seja mantido na faixa de 6,0 a 9,5 .

$\S 2^{\circ}$ Recomenda-se que o teor máximo de cloro residual livre, em qualquer ponto do sistema de abastecimento, seja de $2,0 \mathrm{mg} / \mathrm{L}$.

$\S 3^{\circ}$ Recomenda-se a realização de testes para detecção de odor e gosto em amostras de água coletadas na saída do tratamento e na rede de distribuição de acordo com o plano mínimo de amostragem estabelecido para cor e turbidez nos Quadros 8 e 9.

Os responsáveis pelo controle da qualidade da água de sistema ou solução alternativa de abastecimento de água devem elaborar e aprovar, junto à autoridade de saúde pública, o plano de amostragem de cada sistema, respeitando os planos mínimos de amostragem expressos nos quadros 8, 9, 10 e 11 . 
PRAXEDES, C.I.S., CARRIJO, K.F., FREIRE, R.G.S. Controle físico-químico de água de abastecimento para consumo e uso industrial: sistema de tratamento, métodos de análise e parâmetros legais. PUBVET, Londrina, V. 6, N. 26, Ed. 213, Art. 1420, 2012.

Quadro 8. Número mínimo de amostras para o controle da qualidade da água de sistema de abastecimento, para fins de análises físicas, químicas e de radioatividade, em função do ponto de amostragem, da população abastecida e do tipo de manancial.

\begin{tabular}{|c|c|c|c|c|c|}
\hline \multirow[t]{3}{*}{ PARÂMETRO } & \multirow[t]{3}{*}{$\begin{array}{c}\text { TIPO DE } \\
\text { MANANCIAL }\end{array}$} & \multirow{3}{*}{$\begin{array}{c}\text { SAÍDA DO TRATAMENTO } \\
\text { (NÚMERO DE AMOSTRAS } \\
\text { POR UNIDADE DE } \\
\text { TRATAMENTO) }\end{array}$} & \multirow{2}{*}{\multicolumn{3}{|c|}{$\begin{array}{c}\text { SISTEMA DE DISTRIBUIÇÃO } \\
\text { (RESERVATÓRIOS E REDE) } \\
\text { População abastecida }\end{array}$}} \\
\hline & & & & & \\
\hline & & & $\begin{array}{c}< \\
<50.000 \\
\text { hab. }\end{array}$ & $\begin{array}{l}50.000 \mathrm{a} \\
250.000 \\
\text { hab. }\end{array}$ & $\begin{array}{c}>250.000 \\
\text { hab. }\end{array}$ \\
\hline \multirow[t]{2}{*}{$\begin{array}{l}\text { Cor } \\
\text { Turbidez } \\
\text { pH }\end{array}$} & Superficial & 1 & 10 & $\begin{array}{l}1 \text { para } \\
\text { cada } 5.000 \\
\text { hab. }\end{array}$ & $\begin{array}{l}40+(1 \\
\text { para cada } \\
25.000 \\
\text { hab. })\end{array}$ \\
\hline & Subterrâneo & 1 & 5 & $\begin{array}{l}1 \text { para } \\
\text { cada } \\
10.000 \\
\text { hab. }\end{array}$ & $\begin{array}{l}20+(1 \\
\text { para cada } \\
50.000 \\
\text { hab. })\end{array}$ \\
\hline \multirow[t]{2}{*}{$\operatorname{CRL}\left({ }^{1)}\right.$} & Superficial & 1 & \multicolumn{3}{|c|}{ (Conforme $\S 3^{\circ}$ do artigo 18 ). } \\
\hline & Subterrâneo & 1 & & & \\
\hline Fluoreto & $\begin{array}{l}\text { Superficial ou } \\
\text { Subterrâneo }\end{array}$ & 1 & 5 & $\begin{array}{l}1 \text { para } \\
\text { cada } \\
10.000 \\
\text { hab. }\end{array}$ & $\begin{array}{l}20+(1 \\
\text { para cada } \\
50.000 \\
\text { hab. })\end{array}$ \\
\hline Cianotoxinas & Superficial & $\begin{array}{c}1 \\
\text { (Conforme } \S 5^{\circ} \text { do artigo } \\
18)\end{array}$ & - & - & - \\
\hline Trihalometanos & Superficial & 1 & $1^{(2)}$ & $4^{(2)}$ & $4^{(2)}$ \\
\hline & Subterrâneo & - & $1^{(2)}$ & $1^{(2)}$ & $1^{(2)}$ \\
\hline $\begin{array}{c}\text { Demais } \\
\text { parâmetros }\end{array}$ & $\begin{array}{l}\text { Superficial ou } \\
\text { Subterrâneo }\end{array}$ & 1 & $1^{(4)}$ & $1^{(4)}$ & $1^{(4)}$ \\
\hline
\end{tabular}

NOTAS:

${ }^{(1)}$ Cloro residual livre.

${ }^{(2)}$ As amostras devem ser coletadas, preferencialmente, em pontos de maior tempo de detenção da água no sistema de distribuição.

${ }^{(3)}$ Apenas será exigida obrigatoriedade de investigação dos parâmetros radioativos quando da evidência de causas de radiação natural ou artificial.

${ }^{(4)}$ Dispensada análise na rede de distribuição quando o parâmetro não for detectado na saída do tratamento e, ou, no manancial, à exceção de substâncias que potencialmente possam ser introduzidas no sistema ao longo da distribuição. 
PRAXEDES, C.I.S., CARRIJO, K.F., FREIRE, R.G.S. Controle físico-químico de água de abastecimento para consumo e uso industrial: sistema de tratamento, métodos de análise e parâmetros legais. PUBVET, Londrina, V. 6, N. 26, Ed. 213, Art. 1420, 2012.

Quadro 9. Frequência mínima de amostragem para o controle da qualidade da água de sistema de abastecimento, para fins de análises físicas, químicas e de radioatividade, em função do ponto de amostragem, da população abastecida e do tipo de manancial.

\begin{tabular}{|c|c|c|c|c|c|}
\hline \multirow[t]{3}{*}{ PARÂMETRO } & \multirow[t]{3}{*}{$\begin{array}{l}\text { TIPO DE } \\
\text { MANANCIAL }\end{array}$} & \multirow{3}{*}{$\begin{array}{c}\text { SAÍDA DO } \\
\text { TRATAMENTO } \\
\text { (FREQUÊNCIA POR } \\
\text { UNIDADE DE } \\
\text { TRATAMENTO) }\end{array}$} & \multicolumn{3}{|c|}{$\begin{array}{l}\text { SISTEMA DE DISTRIBUIÇÃO } \\
\text { (RSERVATÓRIOS E REDE) }\end{array}$} \\
\hline & & & \multicolumn{3}{|c|}{ População abastecida } \\
\hline & & & $\begin{array}{l}<50.000 \\
\text { hab. }\end{array}$ & $\begin{array}{c}50.000 \mathrm{a} \\
250.000 \mathrm{hab} .\end{array}$ & $\begin{array}{l}>250.000 \\
\text { hab. }\end{array}$ \\
\hline \multirow{2}{*}{$\begin{array}{c}\text { Cor } \\
\text { Turbidez } \\
\text { pH } \\
\text { Fluoreto }\end{array}$} & Superficial & A cada 2 horas & Mensal & Mensal & Mensal \\
\hline & Subterrâneo & Diária & & & \\
\hline $\mathrm{CRL}^{(1)}$ & Superficial & A cada 2 horas & \multirow{2}{*}{\multicolumn{3}{|c|}{ (Conforme $\S 3^{\circ}$ do artigo 18 ). }} \\
\hline & Subterrâneo & Diária & & & \\
\hline Cianotoxinas & Superficial & $\begin{array}{c}\text { Semanal } \\
\text { (Conforme } \S 5^{\circ} \text { do } \\
\text { artigo 18) } \\
\end{array}$ & - & - & - \\
\hline \multirow[t]{2}{*}{ Trihalometanos } & Superficial & Trimestral & Trimestral & Trimestral & Trimestral \\
\hline & Subterrâneo & - & Anual & Semestral & Semestral \\
\hline $\begin{array}{l}\text { Demais } \\
\text { parâmetros }\end{array}$ & \begin{tabular}{|l|} 
Superficial ou \\
Subterrâneo \\
\end{tabular} & Semestral & Semestral ${ }^{(3)}$ & Semestral $^{(3)}$ & Semestral ${ }^{(3)}$ \\
\hline
\end{tabular}

NOTAS:

${ }^{(1)}$ Cloro residual livre.

${ }^{(2)}$ Apenas será exigida obrigatoriedade de investigação dos parâmetros radioativos quando da evidência de causas de radiação natural ou artificial.

${ }^{(3)}$ Dispensada análise na rede de distribuição quando o parâmetro não for detectado na saída do tratamento e, ou, no manancial, à exceção de substâncias que potencialmente possam ser introduzidas no sistema ao longo da distribuição.

Quadro 10. Número mínimo de amostras mensais para o controle da qualidade da água de sistema de abastecimento, para fins de análises microbiológicas, em função da população abastecida.

\begin{tabular}{|c|c|c|c|c|}
\hline \multirow{2}{*}{ PARÂMETRO } & \multicolumn{4}{|c|}{ SISTEMA DE DISTRIBUIÇÃO (RESERVATÓRIOS E REDE) } \\
\cline { 2 - 5 } & \multicolumn{4}{|c|}{ População abastecida } \\
\cline { 2 - 5 } & $<5.000$ hab. & $\begin{array}{c}5.000 \text { a } 20.000 \\
\text { hab. }\end{array}$ & $\begin{array}{c}20.000 \text { a } \\
250.000 \text { hab. }\end{array}$ & $>250.000$ hab. \\
\hline Coliformes totais & 10 & $\begin{array}{c}1 \text { para cada } \\
500 \text { hab. }\end{array}$ & $\begin{array}{c}30+(1 \text { para } \\
\text { cada } 2.000 \\
\text { hab.) }\end{array}$ & $\begin{array}{c}105+(1 \text { para cada } \\
5.000 \text { hab.) Máximo de } \\
1.000\end{array}$ \\
\hline
\end{tabular}

NOTA: na saída de cada unidade de tratamento devem ser coletadas, no mínimo, 2 (duas) amostra semanais, recomendando-se a coleta de, pelo menos, 4 (quatro) amostras semanais. 
PRAXEDES, C.I.S., CARRIJO, K.F., FREIRE, R.G.S. Controle físico-químico de água de abastecimento para consumo e uso industrial: sistema de tratamento, métodos de análise e parâmetros legais. PUBVET, Londrina, V. 6, N. 26, Ed. 213, Art. 1420, 2012.

Quadro 11. Número mínimo de amostras e frequência mínima de amostragem para o controle da qualidade da água de solução alternativa, para fins de análises físicas, químicas e microbiológicas, em função do tipo de manancial e do ponto de amostragem.

\begin{tabular}{|c|c|c|c|c|}
\hline PARÂMETRO & $\begin{array}{c}\text { TIPO DE } \\
\text { MANANCIAL }\end{array}$ & $\begin{array}{c}\text { SAÍDA DO } \\
\text { TRATAMENTO (para } \\
\text { água canalizada) }\end{array}$ & $\begin{array}{c}\text { NÚMERO DE AMOSTRAS } \\
\text { RETIRADAS NO PONTO } \\
\text { DE CONSUMO (1) (para } \\
\text { cada 500 hab.) }\end{array}$ & $\begin{array}{c}\text { FRËÊNCIA DE } \\
\text { AMOSTRAGEM }\end{array}$ \\
\hline $\begin{array}{c}\text { Cor, turbidez, } \\
\text { pH e coliformes } \\
\text { totais }\end{array}$ & Superficial & 1 & 1 & Semanal \\
\hline CRL $(2)^{(3)}$ & $\begin{array}{c}\text { Supterrâneo } \\
\text { Subterrâneo }\end{array}$ & 1 & 1 & Mensal \\
\hline
\end{tabular}

NOTAS:

${ }^{(1)}$ Devem ser retiradas amostras em, no mínimo, 3 pontos de consumo de água.

(2) Para veículos transportadores de água para consumo humano, deve ser realizada 1 (uma) análise de CRL em cada carga e 1 (uma) análise, na fonte de fornecimento, de cor, turbidez, $\mathrm{pH}$ e coliformes totais com frequência mensal, ou outra amostragem determinada pela autoridade de saúde pública.

${ }^{(3)}$ Cloro residual livre.

E, de acordo com o Art. 62 do Regulamento de Inspeção Industrial e Sanitária de Produtos de Origem Animal - RIISPOA (BRASIL, 2008), nos estabelecimentos de produtos de origem animal destinados à alimentação humana, é considerada básica, para efeito de registro ou relacionamento, a apresentação prévia de boletim oficial de exame de água de abastecimentos, que deve se enquadrar nos padrões microbiológicos e químicos seguintes:

a) não demonstrar, na contagem global mais de 500 (quinhentos) germes por mililitro;

b) não demonstrar no teste presuntivo para pesquisa de coliformes maior número de germes do que os fixados pelos padrões para 5 (cinco) tubos positivos na série de $10 \mathrm{ml}$ (dez mililitros) e 5 (cinco) tubos negativos nas séries de $1 \mathrm{ml}$ (um mililitro) e 0,1 (um décimo de mililitro) da amostra;

c) a água deve ser límpida, incolor, sem cheiro e de sabor próprio agradável;

d) não conter mais de 500 (quinhentas) partes por milhão de sólidos totais;

e) conter no máximo 0,005 g (cinco miligramas) por litro, de nitrogênio amoniacal; 
PRAXEDES, C.I.S., CARRIJO, K.F., FREIRE, R.G.S. Controle físico-químico de água de abastecimento para consumo e uso industrial: sistema de tratamento, métodos de análise e parâmetros legais. PUBVET, Londrina, V. 6, N. 26, Ed. 213, Art. 1420, 2012.

f) ausência de nitrogênio nitroso e de sulfídrico;

g) no máximo $0,002 \mathrm{~g}$ (dois miligramas) de nitrogênio nítrico por litro;

h) no máximo 0,002 g (dois miligramas) de matéria orgânica, por litro;

i) grau de dureza inferior a 20 (vinte);

j) chumbo, menos de 0,1 (um décimo) de parte por milhão;

k) cobre, menos de 3 (três) partes por milhão;

l) zinco, menos de 15 (quinze) partes por milhão;

m) cloro livre, máximo de 1 (uma) parte por milhão, quando se tratar de águas cloradas e cloro residual mínimo de 0,05 (cinco centésimo) partes por milhão;

n) arsênico, menos de 0,05 (cinco centésimos) partes por milhão;

o) fluoretos, máximo de 1 (uma) parte por milhão;

p) selênio, máximo de 0,05 (cinco centésimo) partes por milhão;

q) magnésio, máximo de 0,03 (três centésimos) partes por milhão;

r) sulfatos, no máximo $0,010 \mathrm{~g}$ (dez miligramas), por litro;

s) componentes fenólicos, no máximo 0,001 (uma milésima) parte por milhão.

$\S 10$ - Quando as águas revelem mais de 500 (quinhentos) germes por mililitro, impõe-se novo exame de confirmação, antes de condená-la.

$\S 2^{\circ}$ - Mesmo que o resultado da análise seja favorável, o Departamento de Produtos de Origem Animal (DIPOA) pode exigir, de acordo com as circunstâncias locais o tratamento da água.

\subsection{MÉTODOS DE ANÁLISE}

De acordo com a origem e tratamento recebido, as características das águas potáveis variam, sendo de grande importância o conjunto de determinações físico-químicas, que avaliam essas propriedades. Esses referidos ensaios são destinados à verificação da qualidade de águas provenientes de poços, minas, água mineral e de abastecimento público.

Segundo o Laboratório Nacional de Referência Animal, do Ministério da Agricultura, Pecuária e Abastecimento, as análises físico-químicas para água 
PRAXEDES, C.I.S., CARRIJO, K.F., FREIRE, R.G.S. Controle físico-químico de água de abastecimento para consumo e uso industrial: sistema de tratamento, métodos de análise e parâmetros legais. PUBVET, Londrina, V. 6, N. 26, Ed. 213, Art. 1420, 2012.

serão apresentadas nos itens seguintes (BRASIL, 1981), e também algumas análises segundo o Instituto Adolf Lutz (BRASIL, 2005).

\subsubsection{Características sensoriais ${ }^{2}$}

Segundo (BRASIL, 1981), a água potável deve apresentar-se com aspecto límpido, incolor, inodora e insípida.

\subsubsection{Odor e Sabor}

A avaliação do odor deve ser efetuada no local da colheita para evitar a perda ou aquisição de odores durante o transporte. A água pura não produz sensação de odor ou sabor nos sentidos humanos. Os produtos que conferem odor ou sabor à água são usualmente originados de matéria orgânica ou da atividade biológica de microrganismos, ou ainda de fontes industriais de poluição (MACÊDO, 2002 apud MÁRSICO; MANO, 2008) e minerais dissolvidos. Independente da origem, a presença de sabores e odores são indesejáveis na água potável, não devendo ser um empecilho ao consumo (BRASIL, 2004).

Gostos e odores estranhos - Gostos e cheiros indesejáveis, como de bolor, de terra ou de peixe, são causados pela presença de algas, húmus e outros detritos que naturalmente estão presentes nas fontes de água como rios e lagos.

Cheiro de ovo podre - Este cheiro é causado pela presença de hidrogênio sulfídrico, produzido por bactérias que se encontram em poços profundos e fontes de águas estagnadas por longos períodos.

Gosto de ferrugem/Gosto metálico - O excesso de ferro e de outros metais alteram o sabor e aparência da água. O sabor da água pode apresentar-se metálico, mesmo que visualmente a coloração esteja normal, pois a coloração enferrujada só aparece depois de alguns minutos em contato com o ar.

\footnotetext{
${ }^{2}$ MACÊDO, J.A.B. Introdução à química ambiental. Juiz de Fora: Jorge Macedo, 2002. 487p.
} 
PRAXEDES, C.I.S., CARRIJO, K.F., FREIRE, R.G.S. Controle físico-químico de água de abastecimento para consumo e uso industrial: sistema de tratamento, métodos de análise e parâmetros legais. PUBVET, Londrina, V. 6, N. 26, Ed. 213, Art. 1420, 2012.

Gosto e cheiro de cloro - O cloro é usado pelas estações de tratamento para desinfetar a água. Porém, a presença de cloro prejudica o sabor e o cheiro da água que vai ser utilizada para beber ou na culinária em geral.

PROCEDIMENTO: Coloca-se um pouco de água em um frasco, fecha-se e agita-se fortemente (para facilitar a percepção de odores pode-se aquecer a amostra a $40-60^{\circ} \mathrm{C}$ ). Caso a amostra apresente algum odor, deve-se indicar sua intensidade: muito fraco até muito forte, e natureza: odor metálico, de esgoto, etc. Quando o odor de gás sulfídrico $\left(\mathrm{H}_{2} \mathrm{~S}\right)$ é notado, ele pode ocultar outros odores, devendo ser eliminado da amostra pela adição de acetato de cádmio, prosseguindo-se com a determinação dos odores.

Quanto ao sabor, se há suspeita de que a água está contaminada ou em caso de odores muito desagradáveis, não se deve efetuar esta avaliação.

PROCEDIMENTO: Com a água a aproximadamente $30^{\circ} \mathrm{C}$ leva-se uma quantidade à boca, para bochechar (não é necessário engolir). O sabor pode se apresentar ligeiramente salgado, metálico, amargo.

\subsubsection{Cor}

A presença de cor na água pode ser devida ao seu conteúdo de íns metálicos (geralmente ferro e manganês), plâncton, resíduo industrial, húmus e outros materiais orgânicos e poderá ser expressa como "aparente" ou como "verdadeira". A aparente é originária dos materiais dissolvidos em suspensão. Por sedimentação ou centrifugação dos materiais em suspensão, pode-se determinar a cor verdadeira. Se a cor aparente é a dos materiais em suspensão, pode-se determinar a cor verdadeira. Se a cor aparente é a que se quer determinar, proceda à análise da amostra sem submetê-la à separação de materiais em suspensão (não filtrada). A cor é determinada por comparação visual entre a amostra e soluções coloridas de concentrações conhecidas. A comparação poderá ser feita por via instrumental, com discos coloridos especiais. 
PRAXEDES, C.I.S., CARRIJO, K.F., FREIRE, R.G.S. Controle físico-químico de água de abastecimento para consumo e uso industrial: sistema de tratamento, métodos de análise e parâmetros legais. PUBVET, Londrina, V. 6, N. 26, Ed. 213, Art. 1420, 2012.

Esta avaliação também deverá ser realizada no local. A cor de uma amostra de água está associada ao grau de redução de intensidade que a luz sofre ao atravessá-la (e esta redução dá-se por absorção de parte da radiação eletromagnética), devido à presença de sólidos dissolvidos, principalmente material em estado coloidal orgânico e inorgânico. A água poluída apresenta coloração amarela ou acinzentada. A água rica em ferro e cobre também é amarelada e, em contato com o ar adquire turvação marrom-amarelada. A água que causa manchas pretas possui partículas de manganês.

Segundo a Portaria № 518, de 25 de março de 2004, o valor máximo permitido (VMP) para cor aparente em água potável é de 15uH (Unidade Hazen - PtCo/L) (BRASIL, 2004).

\section{PROCEDIMENTO:}

Comparação ótica por meio de comparador de Hellige (Aqua Tester ${ }^{\circledR}$ ), com disco padrão de cor, comparando-se com água destilada;

Comparação com soluções padrão de cor permanente, obtidas com soluções de reagentes (cloroplatinato de potássio ou cloreto de cobalto), em proporções adequadas. Caso se use o primeiro reagente, uma solução que contenha $1 \mathrm{mg}$ de platina/litro, é considerada uma unidade de cor. É recomendável que a água tenha até 10 unidades, mas tolera-se até 20.

O Aqua-Tester ${ }^{\circledR}$ permite testar faixas muito baixas graças à utilização de tubos Nessler longos (200 mm) que acentuam as cores sob comparação, resultado este não alcançado pelos métodos ordinários. Podem ser realizados 24 diferentes testes em faixas baixas, inclusive o pH de água pura. 
PRAXEDES, C.I.S., CARRIJO, K.F., FREIRE, R.G.S. Controle físico-químico de água de abastecimento para consumo e uso industrial: sistema de tratamento, métodos de análise e parâmetros legais. PUBVET, Londrina, V. 6, N. 26, Ed. 213, Art. 1420, 2012.

\subsubsection{Análises Físico-Químicas}

\subsubsection{Turbidez pelo método turbidimétrico}

A turbidez refere-se à suspensão de materiais de qualquer natureza na água como partículas de sujeira, barro e areia, que retiram o aspecto cristalino da água, deixando-a com uma aparência túrbida e opaca. Ocorre devido à alteração da penetração da luz pelas partículas em suspensão que provocam a sua difusão e absorção. Essas partículas podem ser constituídas por plâncton, bactérias, argila, areia, fontes de poluição e outros (MACÊDO, 2002 apud MÁRSICO; MANO, 2008). Desta forma, a turbidez pode ser referida como a resistência oferecida pelo líquido à passagem de luz branca dependendo não só da concentração de matéria em suspensão como também do tamanho das partículas. Em águas de superfícies, a turbidez pode atingir $2.000 \mathrm{mg} / \mathrm{L}$, expressas em $\mathrm{SiO}_{2}$, enquanto que nas indústrias de alimentos e em água potável esse valor não deve ser superior a $5 \mathrm{mg} / \mathrm{L}$ ou UT (unidade de turbidez) (Brasil, 2004). ${ }^{3}$

Para esta avaliação utiliza-se um turbidímetro cuja calibração é feita com suspensões padrão de sílica sendo a turbidez expressa em mg de $\mathrm{SiO}_{2} /$ litro.

\subsubsection{2 pH}

A uma dada temperatura, a acidez ou a alcalinidade de uma solução é indicada pelo valor do $\mathrm{pH}$ ou pela atividade do íon hidrogênio. $\mathrm{O} \mathrm{pH}$ é definido como o co-logarítmo da atividade do íon hidrogênio ( ' - $\log \mathrm{a}_{\mathrm{H}}{ }^{+}$); para soluções diluídas, a atividade do íon $\mathrm{H}^{+}$é praticamente igual à concentração molar e expressa a acidez do meio. $\mathrm{O}$ valor do $\mathrm{pH}$ para água pura, a $25^{\circ} \mathrm{C}$, é igual a 7 . Como resultado da presença de ácidos ou bases e também da hidrólise de sais dissolvidos, o valor do $\mathrm{pH}$ pode apresentar valores abaixo de 7 (meio ácido) ou

\footnotetext{
${ }^{3}$ MACÊDO, J.A.B. Introdução à química ambiental. Juiz de Fora: Jorge Macedo, 2002. 487p.
} 
PRAXEDES, C.I.S., CARRIJO, K.F., FREIRE, R.G.S. Controle físico-químico de água de abastecimento para consumo e uso industrial: sistema de tratamento, métodos de análise e parâmetros legais. PUBVET, Londrina, V. 6, N. 26, Ed. 213, Art. 1420, 2012.

acima de 7 (meio básico). Para efeitos práticos em análises de água, basta determinar o $\mathrm{pH}$ até segunda casa decimal.

A medida do $\mathrm{pH}$ baseia-se na determinação da atividade dos íons hidrogênio por meio da medida potenciométrica usando um eletrodo de vidro e um de referência ou um eletrodo de vidro combinado. A força eletromotriz medida com o sistema do eletrodo de vidro combinado varia linearmente com $\mathrm{o} \mathrm{pH}$. O instrumento de medida de $\mathrm{pH}$ é, incluindo o eletrodo combinado, calibrado com soluções-tampão de pH conhecido.

PROCEDIMENTO: Ajustar o pHmetro com solução tampão pH 7. Colocar cerca de $70 \mathrm{~mL}$ de amostra em um béquer de $100 \mathrm{~mL}$ e fazer a leitura do $\mathrm{pH}$.

\subsubsection{Sólidos totais secos a $103-105^{\circ} \mathrm{C}$}

Os termos sólidos, sólidos suspensos e sólidos dissolvidos vêm substituir os antigos termos resíduo não filtrável e resíduo filtrável. O termo sólido se refere a matéria suspensa ou dissolvida na água. A designação de sólidos totais é aplicada para o resíduo material deixado no recipiente após a evaporação de uma amostra de água e a subsequente secagem completa a uma temperatura definida, normalmente $105^{\circ} \mathrm{C}$. Os sólidos totais incluem: sólidos totais suspensos, que é a porção dos sólidos totais retidos por um filtro de porosidade igual a $2,0 \mu \mathrm{m}$, e sólidos totais dissolvidos, que é a porção que passa através do filtro.

Os sólidos dissolvidos ou em suspensão, diferenciam-se em fixos e voláteis. "Sólidos fixos" é o termo aplicado ao produto da calcinação do resíduo total, da matéria suspensa ou dissolvida, por um tempo específico a uma determinada temperatura, por exemplo: 2 horas a $500^{\circ} \mathrm{C}$. A perda de peso durante a calcinação é denominada "sólidos voláteis". As determinações de sólidos fixos e voláteis não distinguem precisamente entre a matéria orgânica e a inorgânica, pois a perda por calcinação não é exclusiva de material 
PRAXEDES, C.I.S., CARRIJO, K.F., FREIRE, R.G.S. Controle físico-químico de água de abastecimento para consumo e uso industrial: sistema de tratamento, métodos de análise e parâmetros legais. PUBVET, Londrina, V. 6, N. 26, Ed. 213, Art. 1420, 2012.

orgânico, podendo ocorrer a decomposição ou volatilização de alguns sais minerais.

Sólidos totais são matérias suspensas ou dissolvidas presentes numa amostra de água. Este termo é aplicado ao resíduo de material deixado no recipiente após a evaporação de uma amostra e sua subsequente secagem completa a uma temperatura definida.

Os sólidos totais são determinados pela verificação da massa do resíduo de uma amostra de água, após evaporação e secagem até peso constante, a $103-105^{\circ} \mathrm{C}$.

PROCEDIMENTO: Aqueça, em uma estufa, uma cápsula limpa de platina ou porcelana a $103-105^{\circ} \mathrm{C}$, por no mínimo 3 horas. Retire da estufa, transferindo para um dessecador, até a temperatura ambiente e pese. Meça $100 \mathrm{~mL}$ da amostra de água não filtrada em um balão volumétrico e transfira quantitativamente para a cápsula já pesada. Evapore até secagem em um banho-maria ou numa chapa de aquecimento, evitando que a amostra entre em ebulição. Coloque a cápsula em uma estufa a $103-105^{\circ} \mathrm{C}$ por 3 horas. Transfira a cápsula para um dessecador, deixando atingir o equilíbrio térmico com o ambiente e pese. Repita as operações até obter peso constante ou até que a diferença de peso seja menor do que $4 \%$ da medida anterior. As determinações devem ser feitas em duplicata e os resultados devem concordar em $5 \%$ entre as medidas.

CÁLCULO: $\mathrm{mg} / \mathrm{litro}$ de sólidos totais $=\underline{\mathrm{P} \times 1000}$

$\mathrm{P}=$ peso dos sólidos totais em miligramas

$\mathrm{V}=$ volume da amostra em mililitros

\subsubsection{Dureza Total}

A dureza total é definida como a soma das concentrações de cálcio e magnésio, ambas expressas como carbonato de cálcio, em miligramas por 
PRAXEDES, C.I.S., CARRIJO, K.F., FREIRE, R.G.S. Controle físico-químico de água de abastecimento para consumo e uso industrial: sistema de tratamento, métodos de análise e parâmetros legais. PUBVET, Londrina, V. 6, N. 26, Ed. 213, Art. 1420, 2012.

litro. O ácido etilenodiaminotetracético e seus sais sódicos (EDTA) formam complexos quelados solúveis com certos cátions metálicos. Uma solução contendo íons de cálcio e magnésio, com uma pequena quantidade do indicador negro de eriocromo $\mathrm{T}$, em $\mathrm{pH}(10,0 \pm 0,1)$ torna-se púrpura. Titulando-se essa solução com EDTA, cálcio e magnésio serão quelados e uma viragem de cor púrpura a azul indicará o ponto final.

PROCEDIMENTO: Transferir 50mL da amostra para um frasco Erlenmeyer de $250 \mathrm{~mL}$. Adicione $1 \mathrm{~mL}$ da solução-tampão e pequena porção $(0,05 \mathrm{~g})$ do indicador negro de eriocromo T. Titule com a solução de EDTA 0,01 $\mathrm{M}$ até que a coloração púrpura passe a azul.

A dureza da água se expressa em ppm ou mg/litro, ou então $\mathrm{mg}$ de carbonato de cálcio presente na água, pode variar de 10 a 200 mg/L em água doce, podendo alcançar até $2.500 \mathrm{mg} / \mathrm{L}$ em águas salgadas.

Até 50 ppm - Água mole

De 50 a 100 ppm - Levemente dura

De 100 a 200 ppm - Água dura

Mais de 200 ppm - muito dura

CÁLCULO: $\mathrm{mg}$ de carbonato de cálcio/litro $=\underline{1000 \times \mathrm{V} \times \mathrm{f}}$

$\mathrm{V}^{\prime}$

$V=\mathrm{ml}$ de solução de EDTA 0,01 M gastos na titulação

$\mathrm{f}=$ fator da solução de EDTA $0,01 \mathrm{M}$

$\mathrm{V}^{\prime}=$ volume da amostra

OBS.: No caso de não ser possível analisar a amostra imediatamente, adicionar ácido nítrico até $\mathrm{pH}$ abaixo de 2 e manter sob refrigeração a $4^{\circ} \mathrm{C}$. A análise poderá então ser realizada até 7 dias depois.

2.9.2.5 Oxigênio consumido por matéria redutora de permanganato (matéria orgânica) 
PRAXEDES, C.I.S., CARRIJO, K.F., FREIRE, R.G.S. Controle físico-químico de água de abastecimento para consumo e uso industrial: sistema de tratamento, métodos de análise e parâmetros legais. PUBVET, Londrina, V. 6, N. 26, Ed. 213, Art. 1420, 2012.

A determinação de oxigênio consumido indica a quantidade de substâncias oxidáveis presentes na água. A medida de matéria orgânica fundamenta-se na oxidação de matéria orgânica pelo oxigênio ativo liberado pelo permanganato de potássio quando aquecido em meio ácido forte. O teste não diferencia matéria orgânica estável da matéria orgânica instável. Os nitritos, compostos ferrosos, sulfetos e outras substâncias oxidáveis reduzem o permanganato.

PROCEDIMENTO: Transfira $100 \mathrm{~mL}$ da amostra para um frasco Erlenmeyer de $300 \mathrm{~mL}$. Adicione $5 \mathrm{~mL}$ de ácido sulfúrico a $25 \% \mathrm{v} / \mathrm{v}$. Adicione, com uma bureta, $5 \mathrm{~mL}$ de permanganato de potássio $0,0025 \mathrm{M}$. Aqueça em banho-maria por 30 minutos. Havendo descoloração da solução, adicione mais $10 \mathrm{~mL}$ da solução de permanganato. Caso descore novamente, repita o teste com a amostra diluída a $100 \mathrm{~mL}$. Adicione com uma bureta, uma quantidade de oxalato de sódio 0,00625 M exatamente igual a do total da solução de permanganato de potássio empregada. Leve ao banho-maria até descorar. Titule com solução de permanganato de potássio até coloração rósea.

CÁLCULO: O oxigênio consumido pela amostra (em $\mathrm{mg} / \mathrm{L}$ ) corresponde exatamente ao número de $\mathrm{mL}$ de permanganato de potássio 0,0025 M gasto na titulação da amostra.

\subsubsection{Nitrogênio amoniacal (amônia)}

A presença de amônia nas águas de superfície pode ser resultante da desaminação de compostos orgânicos que contêm nitrogênio por atividade microbiológica ou pela hidrólise da uréia. Pode também ter origem durante o tratamento da água, para formar resíduo combinado de cloro (cloraminas). 
PRAXEDES, C.I.S., CARRIJO, K.F., FREIRE, R.G.S. Controle físico-químico de água de abastecimento para consumo e uso industrial: sistema de tratamento, métodos de análise e parâmetros legais. PUBVET, Londrina, V. 6, N. 26, Ed. 213, Art. 1420, 2012.

\subsection{Método potenciométrico}

O método potenciométrico é aplicado para a determinação de amônia em águas de superfície, domésticas e de resíduos industriais. Interferem nesta metodologia altas concentrações de íons dissolvidos, porém a cor e turbidez não são interferentes. O eletrodo seletivo para amônia possui uma membrana hidrofóbica gás-permeável, para separar a amostra da solução interna do eletrodo (cloreto de amônio). Obtêm-se $\mathrm{NH}_{3}$ aquosa quando, na solução contendo a mistura de $\mathrm{NH}_{3}$ e $\mathrm{NH}_{4}{ }^{+}$, por mudança de $\mathrm{pH}$ com base forte (aproximadamente 11), os íons $\mathrm{NH}_{4}^{+}$se convertem em $\mathrm{NH}_{3}$ aquosa.

PROCEDIMENTO: Transfira $100 \mathrm{~mL}$ da amostra de água para um béquer de $150 \mathrm{~mL}$ e proceda como na curva-padrão. A partir da leitura obtida para amostra, interpole a concentração de $\mathrm{NH}_{3}$, na curva-padrão previamente construída.

\subsection{Método espectrofotométrico}

Este método utiliza o reagente de Nessler que reage, quando adicionado a uma solução diluída de amônia, formando um composto de cor amarelada, o qual pode flocular após certo tempo. A determinação espectrofotométrica deve ser efetuada antes que isto ocorra.

$$
2 \mathrm{~K}_{2}\left[\mathrm{Hgl}_{4}\right]+2 \mathrm{NH}_{3} \rightarrow \mathrm{NH}_{2} \mathrm{Hg}_{2} \mathrm{I}_{3}+4 \mathrm{KI}+\mathrm{NH}_{4} \mathrm{I}
$$

PROCEDIMENTO: Teste qualitativo - Transfira $50 \mathrm{~mL}$ da amostra de água para uma cápsula de porcelana e adicione $1 \mathrm{~mL}$ do reagente de Nessler, sem agitação. Aguarde 10 minutos e observe o desenvolvimento de coloração amarelada, comparando-a com um branco com água bidestilada e deionizada. Se houver aparecimento de cor amarela, proceda a destilação da amostra. 
PRAXEDES, C.I.S., CARRIJO, K.F., FREIRE, R.G.S. Controle físico-químico de água de abastecimento para consumo e uso industrial: sistema de tratamento, métodos de análise e parâmetros legais. PUBVET, Londrina, V. 6, N. 26, Ed. 213, Art. 1420, 2012.

Destilação da amostra - Transfira, para o sistema de destilação, $50 \mathrm{~mL}$ de solução saturada de carbonato de sódio e $500 \mathrm{~mL}$ de água bidestilada e deionizada. Destile aproximadamente $300 \mathrm{~mL}$ e despreze. Continue a destilação, recolha $50 \mathrm{~mL}$ de destilado e adicione $1 \mathrm{~mL}$ de reagente de Nessler. A coloração amarela indica resultado positivo. Continue a destilação até que o teste seja negativo. Esfrie o sistema e substitua o volume restante do balão por $500 \mathrm{~mL}$ da amostra. Adicione $10 \mathrm{~mL}$ da solução-tampão de fosfato de potássio. Proceda à destilação de modo a recolher 6 a $10 \mathrm{~mL}$ de destilado por minuto. Receba o destilado quantitativamente em balão volumétrico de 200 $\mathrm{mL}$. Transfira $50 \mathrm{~mL}$ do destilado para balão volumétrico, adicione $1 \mathrm{~mL}$ de reagente de Nessler e homogeneize. Deixe em repouso por 10 minutos e meça a coloração desenvolvida, em espectrofotômetro a $425 \mathrm{~nm}$ e determine a quantidade de amônia correspondente, usando a curva-padrão previamente estabelecida.

CÁLCULO: Determine a concentração de amônia utilizando a curvapadrão estabelecida com soluções-padrão de cloreto de amônio. Multiplique o resultado por 0,4 , pois foi tomada uma alíquota de $50 \mathrm{~mL}$ de um balão de 200 $\mathrm{mL}$ contendo destilado de $500 \mathrm{~mL}$ da amostra.

NOTA: Para expressar o resultado em nitrogênio amoniacal, o procedimento será o mesmo, bastando multiplicar o resultado obtido para amônia por $14 / 17$ (ou 0,824).

\subsubsection{Nitrogênio albuminoide}

O nitrogênio albuminóide origina-se de grupos amino de proteínas, polipeptídeos e aminoácidos. Estes materiais são constituintes importantes da poluição orgânica na fonte. Após a destilação do nitrogênio amoniacal, a adição de uma solução alcalina de permanganato de potássio produz desprendimento de amônia adicional, que corresponde ao nitrogênio albuminóide. 
PRAXEDES, C.I.S., CARRIJO, K.F., FREIRE, R.G.S. Controle físico-químico de água de abastecimento para consumo e uso industrial: sistema de tratamento, métodos de análise e parâmetros legais. PUBVET, Londrina, V. 6, N. 26, Ed. 213, Art. 1420, 2012.

PROCEDIMENTO: Ao resíduo da destilação resultante da determinação de amônia (ou nitrogênio amoniacal) conforme método do nitrogênio amoniacal, adicione $50 \mathrm{~mL}$ da solução alcalina de permanganato de potássio. Adapte novamente o balão ao sistema refrigerante e destile. Receba $100 \mathrm{~mL}$ do destilado em um balão volumétrico. Transfira $50 \mathrm{~mL}$ para um balão volumétrico, adicione $1 \mathrm{~mL}$ do reagente de Nessler, homogeneíze, meça a coloração amarela desenvolvida, segundo procedimento descrito no método de nitrogênio amoniacal e determine a quantidade correspondente de nitrogênio albuminóide.

CÁLCULO: Determine a concentração de nitrogênio amoniacal utilizando a curva padrão pré-estabelecida com soluções-padrão de cloreto de amônio. Multiplique o resultado pelo fator 0,2 correspondente à alíquota de $50 \mathrm{~mL}$ tomada de um balão volumétrico de $100 \mathrm{~mL}$ contendo o destilado de $500 \mathrm{~mL}$ da amostra.

\subsubsection{Nitrogênio Nitroso (nitritos)}

O íon nitrito corresponde a um estágio intermediário de oxidação do nitrogênio. Forma-se tanto pela oxidação da amônia como pela redução do nitrato. Tais oxidações e reduções podem ocorrer em estações de tratamento de esgotos, em sistemas de distribuição de água e em águas naturais. O nitrito pode ainda ser proveniente de aditivos inibidores da corrosão em instalações industriais. O íon nitrito $\left(\mathrm{NO}_{2}{ }^{-}\right)$é determinado por meio da formação de uma cor vermelho-púrpura produzida em $\mathrm{pH}(2,0-2,5)$ pela reação de diazotação da sulfanilamida com dihidrocloro de $\mathrm{N}$-(1-naftil)etilenodiamina. Na estocagem da amostra de água para a determinação de íons nitrito, nunca use ácido para a sua preservação. A determinação deve ser efetuada na amostra recémcoletada, de modo a prevenir a conversão bacteriana de $\mathrm{NO}_{2}{ }^{-}$ou $\mathrm{NH}_{3}$. Para tempos de espera de 1 a 2 dias, conserve a $4^{\circ} \mathrm{C}$. 
PRAXEDES, C.I.S., CARRIJO, K.F., FREIRE, R.G.S. Controle físico-químico de água de abastecimento para consumo e uso industrial: sistema de tratamento, métodos de análise e parâmetros legais. PUBVET, Londrina, V. 6, N. 26, Ed. 213, Art. 1420, 2012.

CURVA-PADRÃO: Pipete $10 \mathrm{~mL}$ da solução-estoque num balão volumétrico de $100 \mathrm{~mL}$, e complete o volume com água bidestilada e deionizada ( $1 \mathrm{~mL}$ desta solução de $\mathrm{NaNO}_{2}$ contém $0,01 \mathrm{mg}$ de $\mathrm{NO}_{2}{ }^{-}$). A partir desta solução de uso, prepare uma série de soluções de concentrações no intervalo de 0,0 a $0,5 \mathrm{mg} / \mathrm{L}$ em nitrito. Com bureta de $10 \mathrm{~mL}$, adicione quantidades de $0,0,1,2,3,4$ e $5 \mathrm{~mL}$ em balão volumétrico de $100 \mathrm{~mL}$, complete o volume com água bidestilada e deionizada e adicione $4 \mathrm{~mL}$ do reagente de cor. Aguarde de 30 a 45 minutos. Meça a absorbância em espectrofotômetro, utilizando comprimento de onda igual a $543 \mathrm{~nm}$. Construa o gráfico de absorbância em função da concentração da solução-padrão de nitrito (em $\mathrm{mg} \mathrm{NO}_{2}{ }^{-} / \mathrm{L}$ ).

PROCEDIMENTO: Transfira $50 \mathrm{~mL}$ da amostra para um balão volumétrico, adicione $2 \mathrm{~mL}$ do reagente de cor e faça um branco nas mesmas condições da amostra, utilizando água bidestilada e deionizada. Aguarde de 30 a 45 minutos. Meça a absorbância da coloração vermelha desenvolvida a 543 $\mathrm{nm}$, em espectrofotômetro.

NOTA: Prepare a curva-padrão a cada troca da solução reagente de cor.

CÁLCULO: Determine a quantidade de íons nitrito correspondente, usando a curva-padrão, previamente estabelecida.

NOTA: Caso a cor apresente intensidade acima daquela de concentrações usadas para a curva-padrão, repita o procedimento, diluindo a amostra, ou utilize balões volumétricos de maior volume para a leitura final, e considere as diluições no cálculo final. Deverá ser respeitada a faixa de aplicabilidade do método. 
PRAXEDES, C.I.S., CARRIJO, K.F., FREIRE, R.G.S. Controle físico-químico de água de abastecimento para consumo e uso industrial: sistema de tratamento, métodos de análise e parâmetros legais. PUBVET, Londrina, V. 6, N. 26, Ed. 213, Art. 1420, 2012.

\subsubsection{Nitrogênio Nítrico (nitratos)}

O íon nitrato geralmente ocorre em pequenas quantidades nas águas superficiais, mas atinge elevadas concentrações em algumas águas subterrâneas.

O método baseia-se na reação de íons nitrato com ácido fenol dissulfônico e posterior alcalinização com hidróxido de sódio, obtendo-se um composto amarelo. Este composto é o sal sódico do ácido pícrico formado pela nitração do fenol, cuja coloração é medida em espectrofotômetro.

$$
\begin{gathered}
\mathrm{C}_{6} \mathrm{H}_{3}(\mathrm{OH})\left(\mathrm{SO}_{3} \mathrm{H}\right)_{2}+3 \mathrm{HNO}_{3} \leftrightarrow \mathrm{C}_{6} \mathrm{H}_{2}(\mathrm{OH})\left(\mathrm{NO}_{2}\right)_{3}+2 \mathrm{H}_{2} \mathrm{SO}_{4}+\mathrm{H}_{2} \mathrm{O} \\
\mathrm{C}_{6} \mathrm{H}_{2}(\mathrm{OH})\left(\mathrm{NO}_{2}\right)_{3}+\mathrm{NaOH} \leftrightarrow \mathrm{C}_{6} \mathrm{H}_{2}\left(\mathrm{NO}_{2}\right)_{3} \mathrm{ONa}+\mathrm{H}_{2} \mathrm{O}
\end{gathered}
$$

Os íons cloreto interferem no processo porque formam $\mathrm{HCL}$ com o excesso de $\mathrm{H}_{2} \mathrm{SO}_{4}$ contido na mistura ácido fenol dissulfônico/ácido sulfúrico e o $\mathrm{HCl}$ reage com $\mathrm{OHNO}_{3}$ formado:

$$
6 \mathrm{HCl}+2 \mathrm{HNO}_{3} \leftrightarrow 2 \mathrm{NO}+4 \mathrm{H}_{2} \mathrm{O}+3 \mathrm{Cl}_{2}
$$

Acima da concentração de $5 \times 10^{-4} \mathrm{M}$, os íons cloreto podem ser precipitados com $\mathrm{Ag}_{2} \mathrm{SO}_{4}$ e separados previamente. Abaixo dessa concentração a interferência permanece, com diminuição da concentração de nitrato medida, mas com efeito significativo baixo, pois a tolerância legal de nitrato em águas é da ordem de $10 \mathrm{mg} / \mathrm{L}$.

PROCEDIMENTO: Transfira $50 \mathrm{~mL}$ da amostra para uma cápsula de porcelana de $150 \mathrm{~mL}$. Evapore até a secura, em banho-maria. Adicione $1 \mathrm{~mL}$ da solução de ácido fenoldissulfônico. Misture, com um bastão de vidro, o ácido e o resíduo eventualmente presente nas paredes da cápsula. Lave com pequena porção $(10 \mathrm{~mL})$ de água bidestilada e deionizada e adicione 3 a $5 \mathrm{~mL}$ 
PRAXEDES, C.I.S., CARRIJO, K.F., FREIRE, R.G.S. Controle físico-químico de água de abastecimento para consumo e uso industrial: sistema de tratamento, métodos de análise e parâmetros legais. PUBVET, Londrina, V. 6, N. 26, Ed. 213, Art. 1420, 2012.

de solução de hidróxido de sódio a $50 \%$ sob agitação, até obter uma cor amarela estável. Transfira para um balão volumétrico de $50 \mathrm{~mL}$, lavando a cápsula (quando a tonalidade amarela for muito intensa, faça diluições maiores, a partir da amostra original). Complete o volume com água bidestilada e deionizada, filtre se necessário, homogeneíze, aguarde 15 minutos e meça a absorbância em espectrofotômetro, a 410 nm, utilizando como branco água bidestilada e deionizada, preparado nas mesmas condições da amostra. Determine a quantidade de nitrato correspondente, usando a curva-padrão previamente estabelecida.

NOTA: Se a amostra contiver cloretos acima de $30 \mathrm{mg} / \mathrm{L}$, precipite-os em $\mathrm{pH} 1$ (acidule com ácido sulfúrico), usando uma alíquota conveniente de solução de sulfato de prata. Quando a amostra se apresentar excessivamente turva, clarifique-a com uma ponta de espátula de solução de creme de alumina.

CURVA-PADRÃO: A partir da solução-estoque, prepare soluções-padrão de nitrato no intervalo de 0 a $7 \mathrm{mg} \mathrm{NO}_{3}{ }^{-} / \mathrm{L}$. Com bureta de $25 \mathrm{ml}$, adicione quantidades de 0 (branco), 1, 2, 3, 4, 5 e 7 mg, respectivamente, em cápsulas de $150 \mathrm{~mL}$. Evapore até a secura em banho-maria, Adicione em cada uma das cápsulas, $1 \mathrm{~mL}$ da solução de ácido fenoldissulfônico, misture bem com bastão de vidro a mistura e o eventual resíduo nas paredes das cápsulas. Lave com pequena porção (cerca de $10 \mathrm{~mL}$ ) de água bidestilada e deionizada e adicione $5 \mathrm{~mL}$ de solução de hidróxido de sódio a $50 \%$. Misture bem com bastão de vidro até obter cor amarela estável. Transfira para um balão volumétrico de $100 \mathrm{~mL}$, lavando as cápsulas e os bastões com água bidestilada e deionizada. Complete o volume, agite bem, aguarde 15 minutos e meça a absorbância em espectrofotômetro, utilizando comprimento de onda de $410 \mathrm{~nm}$. Construa o gráfico de absorbância em função da concentração da solução-padrão de nitrato (em $\mathrm{mg} \mathrm{NO}_{3}{ }^{-} / \mathrm{L}$ ). 
PRAXEDES, C.I.S., CARRIJO, K.F., FREIRE, R.G.S. Controle físico-químico de água de abastecimento para consumo e uso industrial: sistema de tratamento, métodos de análise e parâmetros legais. PUBVET, Londrina, V. 6, N. 26, Ed. 213, Art. 1420, 2012.

CÁLCULO: Determine a quantidade de nitrogênio nítrico $\left(\mathrm{NO}_{3}{ }^{-}\right)$ correspondente, usando a curva-padrão pré-estabelecida.

OBS.: Nitrato pelo método espectrofotométrico na região do ultravioleta.

\subsubsection{Cloro residual total}

A dosagem do teor de cloro residual que permanece na água após o processo de cloração permite avaliar se a água está em condições de uso e isenta de bactérias patogênicas. Quando o cloro é adicionado à água, uma pequena quantidade, de 0,25 a 0,75 ppm, reage com as impurezas nela contidas. Esse cloro consumido não apresenta propriedades germicidas. Quando a demanda de cloro adicionado é satisfeita, o que restou constitui o cloro residual total (CRT). O cloro residual total encontra-se na forma de cloro residual livre ( $C R L)$ ou cloro combinado com matéria nitrogenada, formando cloraminas. O cloro residual livre está nas formas de ácido hipocloroso $(\mathrm{HClO})$ e de íons.

É um processo colorimétrico de orto-toluidina.

A orto-toluidina em meio ácido é oxidada pelo cloro residual livre e combinado produzindo um composto amarelo proporcional à quantidade de cloro presente. A reação com cloro livre é instantânea, sendo mais lenta com cloro combinado (que se decompõe liberando cloro livre).

Como se trata de uma reação de oxidação, está sujeita a ação de interferentes como nitritos, compostos férricos e mangânicos que vão aumentar aparentemente o conteúdo de cloro residual.

PROCEDIMENTO: Em um tubo de Nessler colocar $100 \mathrm{~mL}$ de amostra e adicionar $5 \mathrm{~mL}$ de solução de orto-tolidina. Misturar bem. Fazer a leitura após 5 minutos em espectrofotômetro a $465 \mathrm{~nm}$. A temperatura da amostra deverá estar em $20^{\circ} \mathrm{C}$. Fazer uma prova em branco, usando $100 \mathrm{~mL}$ de água destilada e procedendo como na amostra. Usar o branco para zerar o aparelho. 
PRAXEDES, C.I.S., CARRIJO, K.F., FREIRE, R.G.S. Controle físico-químico de água de abastecimento para consumo e uso industrial: sistema de tratamento, métodos de análise e parâmetros legais. PUBVET, Londrina, V. 6, N. 26, Ed. 213, Art. 1420, 2012.

Comparar com a curva padrão previamente estabelecida. Expressar o resultado em $\mathrm{mg}$ de cloro residual total/litro.

\subsubsection{Cloro residual livre}

Esta determinação serve para o controle da cloração da água, que pode ser feita com gás cloro ou hipoclorito de sódio ou cálcio. A expressão cloro livre significa o cloro disponível para oxidação de compostos inorgânicos e orgânicos dissolvidos na água (ação bactericida) e inclui a totalidade de $\mathrm{Cl}_{2}, \mathrm{ClO}^{-}$e $\mathrm{HClO}$. A água potável não deve conter menos de 0,1 mg/litro, nem mais de 0,3 mg/litro de cloro livre (em certas situações industriais, usa-se valores mais elevados).

A determinação de cloro livre deve ser feita logo após a tomada da amostra.

Utiliza-se o método colorimétrico, com a reação entre o cloro e a ortotoluidina, que forma um composto amarelado, cuja intensidade de cor pode ser medida em espectrofotômetro e comparada com curva padrão de hipoclorito de sódio.

PROCEDIMENTO: Em tubo de Nessler colocar $100 \mathrm{ml}$ de amostra e $5 \mathrm{ml}$ de solução de orto-toluidina. Agitar imediatamente e adicionar imediatamente $5 \mathrm{ml}$ de solução de meta-arsenito de sódio. Fazer um branco em paralelo. Ler em espectrofotômetro a $465 \mathrm{~nm}$. Comparar com a curva padrão previamente estabelecida. Se não tiver meta-arsenito de sódio a determinação poderá ser realizada, fazendo-se a leitura imediatamente após a adição da orto-toluidina. Expressar o resultado em $\mathrm{mg}$ de cloro residual livre/litro.

\subsubsection{Cloro residual combinado}

Mg de cloro residual combinado/litro = cloro residual total menos cloro residual livre. 
PRAXEDES, C.I.S., CARRIJO, K.F., FREIRE, R.G.S. Controle físico-químico de água de abastecimento para consumo e uso industrial: sistema de tratamento, métodos de análise e parâmetros legais. PUBVET, Londrina, V. 6, N. 26, Ed. 213, Art. 1420, 2012.

\subsubsection{Cloretos}

Íons cloreto podem ser encontrados em águas provenientes de depósitos minerais e de fontes poluídas, tais como esgotos e resíduos industriais. Em solução com pH entre 6,0 e 7,5, íons cromato são usados para indicar o ponto final da titulação de íons cloreto com íons prata. O cloreto de prata é precipitado quantitativamente antes do cromato de prata, de cor vermelha.

PROCEDIMENTO: Pipete $50 \mathrm{~mL}$ da amostra para uma cápsula de porcelana de $150 \mathrm{~mL}$. Aqueça em banho-maria até reduzir o volume a aproximadamente $20 \mathrm{~mL}$. Adicione 4 gotas do indicador cromato de potássio. Titule com a solução de nitrato de prata em bureta de $10 \mathrm{~mL}$ até o aparecimento de uma coloração avermelhada.

NOTA: Íons brometo e iodeto interferem nessa reação.

CÁLCULO: $\underline{M \times v \times 35,453 \times 1000}=\mathrm{mg}$ de cloreto por litro

$$
v_{a}
$$

$M=$ molaridade do nitrato de prata

$v=$ volume de nitrato de prata gasto na titulação

$v_{a}=$ volume da amostra

\subsubsection{Fluoreto pelo método potenciométrico}

O método potenciométrico com eletrodo de íon seletivo de fluoreto é adequado para concentrações de íons fluoreto acima de $0,2 \mathrm{mg} / \mathrm{L}$. A adição de solução tampão elimina algumas interferências e, nestes casos, evita-se a destilação prévia. As vantagens deste método são: alta seletividade, simplicidade e rapidez. O eletrodo de fluoreto é um sensor íon seletivo. O elemento principal do eletrodo de fluoreto, basicamente, é um monocristal de fluoreto de lantânio, através do qual se estabelece um potencial entre a 
PRAXEDES, C.I.S., CARRIJO, K.F., FREIRE, R.G.S. Controle físico-químico de água de abastecimento para consumo e uso industrial: sistema de tratamento, métodos de análise e parâmetros legais. PUBVET, Londrina, V. 6, N. 26, Ed. 213, Art. 1420, 2012.

solução de fluoreto interna do eletrodo e a solução cuja concentração do referido íon pretende-se determinar. O cristal entra em contato com a amostra em uma face e uma solução interna de referência com a outra face. A cela eletrolítica pode ser representada por:

$\mathrm{Zg} / \mathrm{AgCl}, \mathrm{Cl}(0,3 \mathrm{M}), \mathrm{F}(0,001 \mathrm{M}) / \mathrm{LaF}_{3} /$ amostra/ eletrodo de referência

$O$ eletrodo de íon fluoreto pode ser usado com um eletrodo de referência de calomelano em qualquer pHmetro com precisão de $0,1 \mathrm{mV}$ (milivolt). A atividade do íon depende da força iônica total, do $\mathrm{pH}$ e das espécies complexantes de íon fluoreto na solução. A adição de um tampão adequado permite manter a força iônica uniforme e constante, ajustar o $\mathrm{pH}$ e liberar $\mathrm{o}$ íon fluoreto dos complexos existentes.

PROCEDIMENTO: Meça $50 \mathrm{~mL}$ da amostra e transfira para um béquer de plástico de $100 \mathrm{~mL}$. Adicione, com pipeta volumétrica, $5 \mathrm{~mL}$ da solução-tampão T3. Coloque uma barra magnética no béquer e homogeneíze sob agitação magnética. Com o potenciômetro e os eletrodos calibrados, proceda à leitura das amostras. Faça a leitura das amostras utilizando agitação magnética constante e velocidade similar à que foi utilizada para a leitura dos padrões.

\subsubsection{Ferro}

Os compostos de ferro, muito abundantes na natureza, são integrantes da composição química do solo, das rochas e da matéria vegetal. Em condições redutoras, o ferro existe no estado ferroso. Em águas expostas ao ar ou em condições oxidantes, os íons ferrosos são oxidados ao estado férrico, o qual se hidrolisa formando hidróxido de ferro III insolúvel. O ferro ocorre em solução aquosa, em estado coloidal que pode ser peptizado por matéria orgânica, em complexos inorgânicos ou orgânicos ou em partículas em suspensão.

PROCEDIMENTO: Agite bem a amostra e transfira $50 \mathrm{~mL}$ para um béquer de $250 \mathrm{~mL}$. Adicione $1 \mathrm{~mL}$ de $\mathrm{HCl} 50 \%$ (v/v) e $1 \mathrm{~mL}$ de solução de cloreto de 
PRAXEDES, C.I.S., CARRIJO, K.F., FREIRE, R.G.S. Controle físico-químico de água de abastecimento para consumo e uso industrial: sistema de tratamento, métodos de análise e parâmetros legais. PUBVET, Londrina, V. 6, N. 26, Ed. 213, Art. 1420, 2012.

hidroxilamina $10 \%(\mathrm{~m} / \mathrm{v})$. Ferva até que o volume se reduza a 15 ou $20 \mathrm{~mL}$. Esfrie à temperatura ambiente. Adicione $5 \mathrm{~mL}$ de tampão acetato e $2 \mathrm{~mL}$ de solução de fenantrolina. Transfira para um balão volumétrico de $50 \mathrm{~mL}$, lavando as paredes do béquer e complete o volume com água bidestilada e deionizada. Homogeneíze e deixe em repouso por 10 a 15 minutos, para o completo desenvolvimento da cor. Acerte o "zero" do equipamento com a prova em branco. Meça a absorbância da amostra analisada.

NOTA: Quando o teor de ferro na amostra for superior a $1 \mathrm{mg} / \mathrm{L}$, dilua, cuidadosamente, uma alíquota da amostra original até $50 \mathrm{~mL}$ e proceda de maneira análoga à descrita no procedimento. Jamais dilua a solução colorida final.

CÁLCULO: Obtenha a concentração da amostra diretamente da curvapadrão.

\subsubsection{Cianeto - Prova de Pertusi-Gastaldi}

PROCEDIMENTO: Em uma placa de toque, coloque uma gota de acetato de cobre a $30 \% \mathrm{~m} / \mathrm{v}$, cinco gotas da solução saturada de acetato de benzidina em ácido acético a $10 \%$ e $0,5 \mathrm{~mL}$ da amostra. Em presença de íons cianeto, aparecerá uma coloração azul característica.

NOTA: Os oxidantes e os ânions que complexam com o cobre (I) também reagem nesta prova. São interferentes: iodetos, sulfetos, etc.

2.9.2.17 Metais totais por espectrometria de emissão atômica com plasma de argônio indutivamente acoplado

Este método é aplicável à determinação de metais totais (prata, alumínio, bário, cálcio, cobre, cromo, ferro, potássio, magnésio, manganês, sódio, fósforo e zinco) em água para consumo humano. Os metais são 
PRAXEDES, C.I.S., CARRIJO, K.F., FREIRE, R.G.S. Controle físico-químico de água de abastecimento para consumo e uso industrial: sistema de tratamento, métodos de análise e parâmetros legais. PUBVET, Londrina, V. 6, N. 26, Ed. 213, Art. 1420, 2012.

determinados usando a técnica de espectrometria de emissão atômica por plasma de argônio indutivamente acoplado (ICP OES).

REAGENTES: Soluções-padrão estoque monoelementares de $1000 \mathrm{mg} / \mathrm{L}$ de: alumínio, prata, bário, cromo, cobre e manganês para análise espectrométrica, com certificado de análise e incerteza associada.

Soluções-padrão estoque monoelementares de $10000 \mathrm{mg} / \mathrm{L}$ de: cálcio, ferro, fósforo, magnésio, potássio, sódio e zinco para análise espectrométrica, com certificado de análise e incerteza associada.

NOTA: a solução-padrão de prata deve ser preparada separadamente da solução-padrão multi-elementar, pois este metal forma precipitado com haletos. Recomenda-se que as soluções para a construção da curva-padrão da prata sejam preparadas no dia do ensaio.

PROCEDIMENTO: Otimize os parâmetros instrumentais segundo o manual de instruções do fabricante.

CURVA-PADRÃO: Prepare as soluções-padrão multi-elementares de trabalho para a construção da curva-padrão com seis pontos, incluindo o branco, a partir de uma solução-padrão intermediária, levando em consideração a sensibilidade do equipamento e a faixa linear de trabalho para cada elemento. As soluções são preparadas em ácido nítrico a $0,2 \% \mathrm{v} / \mathrm{v}$ e conservadas em frascos de polietileno. É recomendável que o ponto intermediário da curva-padrão compreenda o limite estabelecido pela legislação, para cada elemento.

DETERMINAÇÃO: Zere o equipamento com solução de ácido nítrico a $0,2 \% \mathrm{v} / \mathrm{v}$. Estabeleça as curvas padrão para cada elemento a ser determinado usando regressão não-linear. Verifique a calibração após analisar um número de amostras, utilizando uma das soluções-padrão da curva. Se a leitura apresentar uma variação maior que a estabelecida pelo laboratório, deve-se 
PRAXEDES, C.I.S., CARRIJO, K.F., FREIRE, R.G.S. Controle físico-químico de água de abastecimento para consumo e uso industrial: sistema de tratamento, métodos de análise e parâmetros legais. PUBVET, Londrina, V. 6, N. 26, Ed. 213, Art. 1420, 2012.

recalibrar. Se necessário, dilua a amostra para que a leitura fique inserida na faixa-linear da curva-padrão. A diluição também deve ser feita com ácido nítrico a $0,2 \% \mathrm{v} / \mathrm{v}$.

CÁLCULO: Como o metal é determinado diretamente na amostra de água, o valor lido no equipamento é o próprio valor da concentração, a não ser que alguma diluição ou pré-concentração tenha sido necessária. Nesse caso, deve-se dividir ou multiplicar o valor da leitura obtida pelo fator de diluição ou da pré-concentração.

\section{CONCLUSÃO}

Atualmente a análise da água é utilizada não somente para determinar sua composição físico-química e microbiológica, mas também como uma forma de controle de qualidade, visto que através das análises pode-se verificar se há alterações e/ou quais tratamentos ela ainda deve ser submetida, e ainda se deve ou não ser utilizada para determinado fim.

Porém, antes da definição da análise, deve-se conhecer a natureza do manancial e do tratamento submetida, para que se tenha sucesso na obtenção dos resultados.

\section{REFERÊNCIAS BIBLIOGRÁFICAS}

BRASIL. Ministério da Agricultura, Pecuária e Abastecimento. Departamento de Inspeção de Produtos de Origem Animal (DIPOA). Decreto Lei no 30.691, de 29 de março de 1.952. Alterado pelos Decretos no 1.255 de 25/06/62, no 1.236 de 02/09/94, no 1.812 de 08/02/96, no 2.244 de 04/06/97 e. no 6385, de 27/02/2008 Regulamento da Inspeção Industrial e Sanitária de Produtos de Origem Animal (RIISPOA). Brasília: RIISPOA, 2008.

- Ministério da Agricultura. Secretaria Nacional de Defesa Agropecuária. Laboratório de Referência Animal. Métodos analíticos oficiais para controle de produtos de origem animal e seus ingredientes. II - Métodos Físico-Químicos. Brasília, 1981.

- Ministério da Saúde. Portaria n 518, de 25 de março de 2004. Estabelece os procedimentos e responsabilidades relativos ao controle e vigilância da qualidade da água para consumo humano e seu padrão de potabilidade, e dá outras providências. 
Ministério da Saúde. Agência Nacional de Vigilância Sanitária. Instituto Adolfo Lutz. Métodos Físico-Químicos para análise de alimentos, 4 ed., Brasília, 2005.

CETESB - Ciclo das águas. Companhia de Tecnologia de Saneamento Ambiental. Secretaria do Meio Ambiente do Estado de São Paulo. 2008. Disponível em: <http://www.cetesb.sp.gov.br/Agua/rios/ciclo.asp>. Acessado em 09/08/2008.

FERREIRA JÚNIOR, L.G. Monitoramento e avaliação da contaminação de água potável através do método do substrato definido - cromogênico a nível municipal do SUS. Rio de Janeiro, 2002. 121f. Dissertação (Mestrado em Engenharia Sanitária e Saúde Pública), Escola Nacional de Saúde Pública, Fundação Oswaldo Cruz, Rio de Janeiro, 2002.

FUNDAÇÃO NACIONAL DE SAÚDE - FUNASA. Curso de Estação de Tratamento de Água. Ênfase em Vigilância da Saúde. Brasília: 2003. CD-ROM.

LIRA, O.L. Manual Técnico de Controle da Qualidade da água para consumo humano destinados a operadores de ETA. Belo Horizonte: FUNASA, 2000. 69p.

MÁRSICO, E.T.; MANO, S.B. Tópicos em controle físico-químico de produtos de origem animal. Niterói: Universidade Federal Fluminense, 2008. 125p.

ORGANIZAÇÃO PANAMERICANA DA SAÚDE - OPAS. 2.ed.Ginebra: OPAS, 1995.195 p.

ORGANIZAÇÃO DAS NAÇÕES UNIDAS - ONU. Declaração Universal dos Direitos da Água.

Biblioteca Virtual de Direitos Humanos. Universidade de São Paulo. São Paulo (SP). Disponível em: <http://www.direitoshumanos.usp.br

/counter/Onu/MeioAmbiente/texto/texto_7.html>. Acessado em 03/08/2008.

PACIFIC INSTITUTE. The World's Water - Bottled Water Consumption by Country, 1997 to 2004. 2008. Disponível em: <http://www.worldwater.org/data20062007/Table10.pdf>. Acessado em: 06/08/2008.

PARDI M. C.; SANTOS I.F.; SOUZA E. R.; PARDI H. S. Ciência, Higiene e Tecnologia da carne: Ciência e higiene da carne: tecnologia da sua obtenção e transformação. 2. ed. Goiânia: Ed. UFG, 2001.623 p. v.1.

QUIMICA AMBIENTAL. Tratamento da água. Educação ambiental e Cidadania. USP, São Paulo (SP), 2008. Disponível em: <http://www.usp.br/qambiental/tratamento Agua.html\#cicloDaAgua>, Acessado em 03/08/2008.

SILVA, D J. Análise de Alimentos (métodos químicos e biológicos). 2.ed. Viçosa, MG: UFV, Imprensa Universitária, 1990. 165 p.

UNIVERSIDADE DA ÁGUA. Água no planeta. Disponível em:

<http://www.uniagua.org.br/website/default.asp?tp=3\&pag=aguaplaneta.htm>. Acessado em 29/07/2008.

ZIMBRES, E. Ciclo hidrológico. 2008. Disponível em: http://www.dicionario.pro.br/dicionario/index.php/Ciclo_hidrol\%C3\%B3gico. Acessado em: 20/05/2008 (O ciclo da água. Evans, J.M. /USGS, modificado por ZIMBRES, E.). 